\title{
Early Miocene herpetofaunas from the Greek localities of Aliveri and Karydia - bridging a gap in the knowledge of amphibians and reptiles from the early Neogene of southeastern Europe
}

\author{
Georgios L. Georgalis ${ }^{\mathrm{a}, \mathrm{b}}$, Andrea Villab ${ }^{\mathrm{b}}$, Martin Ivanov ${ }^{\mathrm{c}}$, Socrates Roussiakis ${ }^{\mathrm{d}}$, Panagiotis Skandalos ${ }^{\mathrm{d}}$ and \\ Massimo Delfinob,e (iD \\ aDepartment of Geosciences, University of Fribourg, Fribourg, Switzerland; 'bipartimento di Scienze della Terra, Università di Torino, Torino, Italy;

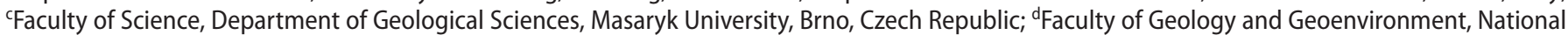 \\ \& Kapodistrian University of Athens, Athens, Greece; eInstitut Català de Paleontologia Miquel Crusafont, Universitat Autònoma de Barcelona, Edifici \\ ICTA-ICP, Barcelona, Spain
}

\begin{abstract}
We here describe new remains of amphibians and reptiles from the early Miocene (MN 4) of two different Greek localities, Aliveri and Karydia. The newly described material consists of urodelans, alytids, indeterminate anurans, turtles, crocodylians, lacertids, indeterminate scincomorphs, anguids, colubrids, viperids, and indeterminate snakes. The presence of the frog Latonia cf. gigantea in Greece is documented for the first time. Additionally, the presence of viperids in Aliveri implies a much wider distribution for these snakes during the early Miocene of Europe. Of special interest is the presence of a peculiar colubrid that seems to possess a hitherto unknown vertebral structure, which is herein defined as the 'paracentral ridge'. Although incomplete, the new material has important taxonomic and biogeographic implications, as it enhances our understanding of southeastern European herpetofaunas from the early Miocene, a time period that was characterised by major dispersal and extinction events and climatic change that affected the whole continent.
\end{abstract}

\section{KEYWORDS \\ Amphibia; Reptilia; Miocene; taxonomy; biogeography; Greece}

\section{Introduction}

The early Miocene was an important time interval for European vertebrate faunas, as it witnessed major dispersal events from both Africa and Asia, but also important climatic changes characterised by higher temperatures, all resulting in the emergence of new palaeoenvironments, extinction events, and drastic faunal turnovers (Rögl 1999; Böhme 2003). The most important studies about these early Miocene events have so far focused primarily on mammals (e.g. Koufos et al. 2005), but knowledge of the respective coeval amphibians and reptiles is far more limited and poorly documented (Ivanov 2001; Delfino et al. 2003; Rage and Roček 2003; Čerňanský 2012; Rage 2013). The situation is even more puzzling for the southeastern portions of Europe, where the known early Miocene herpetofauna is limited to only few sporadic occurrences (Đurić 2016; Georgalis et al. 2013; Georgalis, Villa and Delfino 2016; Vasileiadou et al. 2017).

We try here to fill this gap by describing new fossil amphibians and reptiles from two distinct Greek localities, Aliveri and Karydia, both pertaining to the MN 4 zone (Burdigalian, early Miocene). Up to now, only a chamaeleonid lizard (Chamaeleo cf. andrusovi) had been described from Aliveri (Georgalis, Villa and Delfino 2016). The turtles from both localities were only preliminarily mentioned with no descriptions or figures by Georgalis and Kear (2013) as 'Emydidae (?) indet.' (for Aliveri-2) and 'Testudinata indet'. (for Karydia-2). We analyze the taxonomic

affinities of the new Aliveri and Karydia specimens and additionally discuss biogeographic implications that enhance our comprehension of the herpetofaunas of southeastern Europe.

Abbreviations: AL1a, Aliveri 1a Site; AL1b, Aliveri 1b Site; AL1980NQ, Aliveri 1980 New Quarry Site; AL2, Aliveri 2 Site; AMPG, Athens Museum of Palaeontology and Geology, National and Kapodistrian University of Athens, Athens, Greece; HNHM, Hungarian Natural History Museum, Budapest, Hungary; KR2, Karydia-2 Locality; MDHC, Massimo Delfino Herpetological Collection, University of Torino, Torino, Italy; MNCN, Museo Nacional de Ciencias Naturales, Madrid, Spain; MNHN, Muséum national d'Histoire naturelle, Paris, France; NHMW, Naturhistorisches Museum Wien, Vienna, Austria; NMP, Národní Muzeum Praha, Prague, The Czech Republic; UU, University of Utrecht, Utrecht, The Netherlands; ZZSiD, Institute of Systematics and Evolution of Animals, Polish Academy of Sciences, Kraków, Poland.

\section{Materials and methods}

The majority of specimens described herein belongs to the collection of the UU, whereas the remaining of the described material belongs to the AMPG. Comparative material includes multiple skeletons of extant frogs, salamanders, turtles, lizards, and snakes held in HNHM, MDHC, MNCN, MNHN, NHMW, NMP, and ZZSiD. 


\section{Geological settings}

The fossiliferous localities of Aliveri and Karydia, together with those of Gavathas and Lapsarna (both on Lesvos Island), Nostimo (Western Macedonia), and possibly of Kalimeriani (Euboea Island), are among the few early Miocene localities in Greece that have yielded fossils of terrestrial vertebrates (Koufos et al. 2003; Koufos 2006; Vasileiadou and Zouros 2012; Georgalis et al. 2013; Koufos 2013; Georgalis, Villa and Delfino 2016; Vasileiadou et al. 2017).

The locality of Aliveri is situated on the island of Euboea (or Evia) in the administrative region of Central Greece (Figure 1) and was discovered in 1977 by a Dutch-Greek team consisting of Albert van der Meulen, Hans de Bruijn and Georgios Katsikatsos (de Bruijn and van der Meulen 1979; Doukas 2003; van den Hoek Ostende et al. 2015). The Aliveri locality represents a lignitic pit in the Neogene Kymi-Aliveri Basin (de Bruijn et al. 1980). The fossil material from the Aliveri locality originates from four different sites, Aliveri 1a, Aliveri 1b, Aliveri 2, and Aliveri $1980 \mathrm{New}$ Quarry. All of these sites are considered coeval. Unfortunately, the locality is not accessible anymore due to housing development in the area. Recently, van den Hoek Ostende et al. (2015) revised the fauna of Aliveri and also provided a history of past discoveries and studies. Though initially correlated to the MN 3 zone (de Bruijn et al. 1980), the fauna of Aliveri is now referred to earliest MN 4, with an estimated age between 18 and $17.5 \mathrm{Ma}$ (Koufos 2006; van den Hoek Ostende et al. 2015). According to van den Hoek Ostende et al. (2015), the Aliveri assemblage is unique in representing the earliest European Neogene locality documenting the co-occurrence of eastern immigrants that include the rodents Cricetodon, Eumyarion, Democricetodon, Megacricetodon, and the insectivore Galerix symeonidisi, in combination with the presence of European taxa. Besides the abundant micromammal taxa, large mammals are also known, being represented by the equid Anchitherium, two species of the palaeomerycid Lagomeryx, the bovid Eotragus, and the carnivorans Euboictis aliveriensis and Palaeogale sp. (van den Hoek Ostende et al. 2015). As for the herpetofauna, up to now, only chamaeleonid lizards have been described from Aliveri (Georgalis, Villa and Delfino 2016), whereas turtles were only briefly mentioned by Georgalis and Kear (2013).

The locality of Karydia is situated in northeastern Greece, in the administrative region of East Macedonia and Thrace (Figure 1). It is located northeast of the town of Komotini, about $800 \mathrm{~m}$ south of the Karydia village, and was discovered in 1989 by Hans de Bruijn and Dimitris Foussekis (Doukas 2005). The locality belongs to the Neogene sedimentary sequence of the Thrace Basin. According to Doukas and van den Hoek Ostende (2006), the material was collected from a clay quarry, from three fossiliferous levels around a hill (Karydia-1, -2 , and -3 [herein dubbed as KR1-KR3]), and all levels are considered synchronous, although the lithology indicates a slightly older age for KR3. Similarly to Aliveri, the Karydia assemblage is attributed to MN 4. However, the rodent fauna implies a younger age for Karydia. Theocharopoulos (2000) argued that Democricetodon franconicus from Aliveri is more primitive than conspecific material from Karydia, indicating a slightly younger age for the latter locality. A slightly younger age for Karydia is also supported by the more advanced evolutionary stage of the rodents Cricetodon and Anomalomys, and the presence in Karydia of Ligerimys instead of Pseudotheridomys (Doukas 2003; Koufos 2006; van den Hoek Ostende et al. 2015). The younger age of Karydia relative to that of Aliveri, is also supported by insectivores, as the former locality is characterised by the presence of Galerix kostakii, a species considered as a descendant of $G$. symeonidisi, the latter being present in Aliveri (Doukas and van den Hoek Ostende 2006). Similarly to Aliveri, Karydia shares

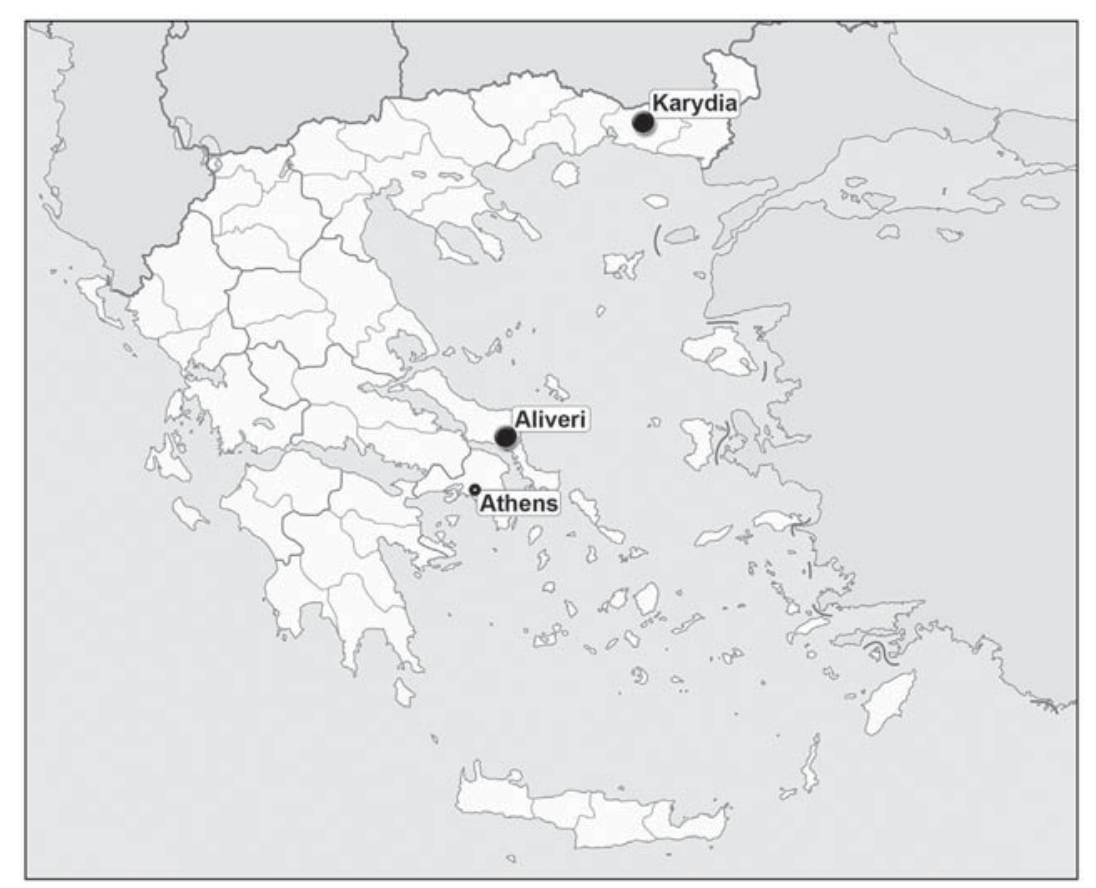

Figure 1. Map of Greece with indication of the localities of Aliveri and Karydia. Source: https://commons.wikimedia.org/wiki/File:Greece_location_map.svg 
certain congeneric mammal taxa with early Miocene Anatolian localities (e.g. de Bruijn, 2017). No large mammals are known from Karydia and no herpetofauna has been described to date either. It should be highlighted that Karydia has produced far less fossil material in comparison to Aliveri.

Systematic Palaeontology

Amphibia Blainville, 1816

Urodela Duméril, 1806

Urodela indet. (Figure 2)

Material. KR3: a tibia (AMPG KR3 037).

Description. The tibia is medium-sized, with a total length of $6 \mathrm{~mm}$ (Figure 2). It is moderately slender and presents a well-developed tibial crest, whose free portion is broken off. A second low ridge is visible on the ventral surface of the bone, running along its entire length.

Remarks. This single, isolated tibia is fully comparable with a medium-sized urodelan in terms of general morphology. A lack of detailed knowledge about the skeletal anatomy of modern salamanders, however, hinders identifying further taxonomic significant features of the Karydia fossil element.

Anura Fischer von Waldheim, 1813

Alytidae Fitzinger, 1843

Latonia Meyer, 1843

Latonia gigantea (Lartet, 1851)

Latonia cf. gigantea (Figure 3)

Material. KR3: 15 maxillae (AMPG KR3 004, AMPG KR3 005, AMPG KR3 014-AMPG KR3 016, AMPG KR3 027, AMPG KR3 030, AMPG KR3 048-AMPG KR3 055), a frontoparietal (AMPG KR3 038), two praearticulars (AMPG KR3 028 and AMPG KR3 029), two trunk vertebrae (AMPG KR3 031 and AMPG KR3 033), a sacral vertebra (AMPG KR3 032), and four ilia (AMPG KR3 011, AMPG KR3 026, AMPG KR3 044, and AMPG KR3 045).

\section{Description}

Maxillae. These elements are small and incomplete (Figure 3(A)(F)). The longest fragments, AMPG KR3 005 and AMPG KR3 015 , slightly exceed 5 and $6 \mathrm{~mm}$ respectively. The lateral surface is generally smooth. Only AMPG KR3 015 shows a light dermal ornamentation made up by small and indistinct tubercles along the high processus zygomaticomaxillaris, but the presence, or not, of a similar ornamentation in the other specimen cannot be discerned since this part of the bone is missing. Some of the Karydia-3 specimens (e.g. AMPG KR3 005) preserve, at least partially, the anterior end and the processus palatinus. The latter is narrow, anteriorly inclined and gutter-shaped. The portion of the maxilla anterior to the processus palatinus is rather long, being delimited laterally by a high lamina anterior. The lamina horizontalis narrows towards the anterior end. Its dorsal surface displays a rather deep and narrow fossa maxillaris just anterior to the processus palatinus. The posterior end is preserved, at least partially, only in AMPG KR3 015, AMPG KR3 016, and AMPG KR3 027. In these specimens, the lamina horizontalis slightly narrows towards the posterior end and develops a rather long and slender processus pterygoideus. The tooth row extends posteriorly to the end of the lamina horizontalis. A shallow posterior depression is recognizable, including a narrow foramen by its contact with the lamina horizontalis. The depression is not marked by ridges anteriorly. The margo orbitalis is strongly concave.

Frontoparietal. The fragmentary frontoparietal is rather small, with a total preserved length of roughly $4 \mathrm{~mm}$ (Figure $3(\mathrm{G})-(\mathrm{H})$ ). The anterior end of the bone is missing, whereas posteriorly the bone misses the entire left corner, most of the right processus paraoccipitalis and the right lateral margin. In the entire preserved portion of the bone, the facies dorsalis is rather distinctly narrower than the pars contacta, and the tectum supraorbitale
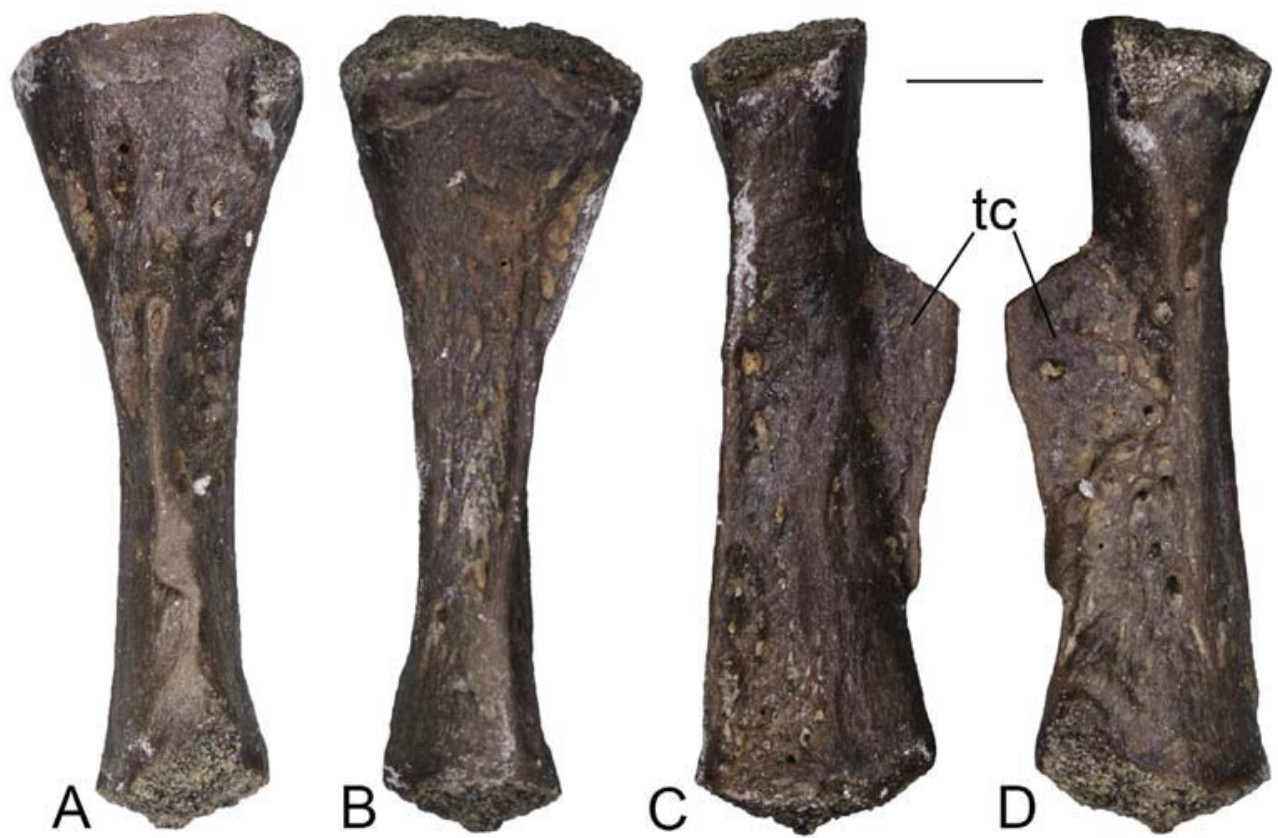

Figure 2. Urodela indet. from Karydia-3: left tibia (AMPG KR3 037) in dorsal (A), ventral (B), lateral (C) and medial (D) views. Scale bar $=1 \mathrm{~mm}$. Abbreviations: tc, tibial crest. 

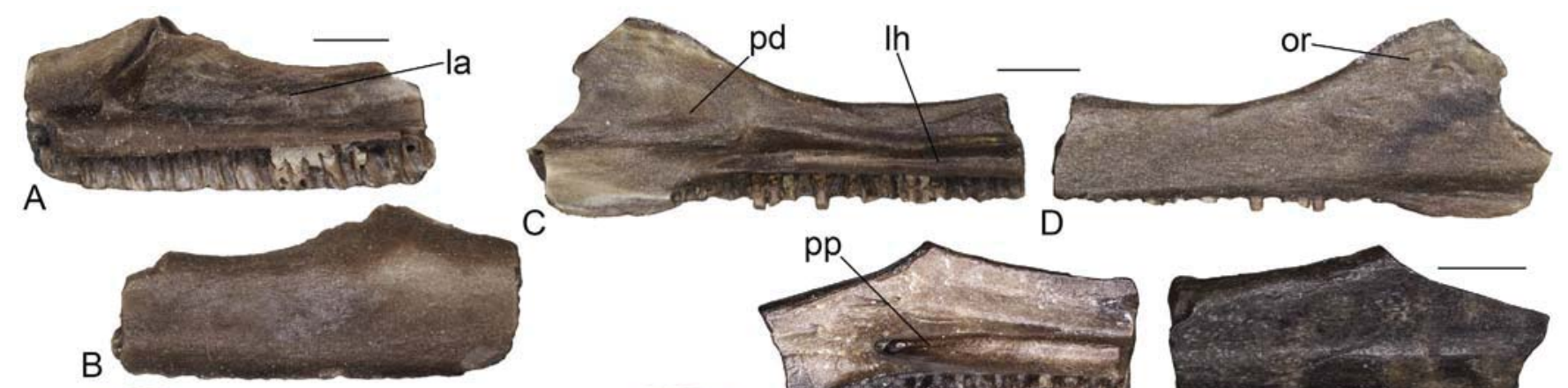

C $p p$

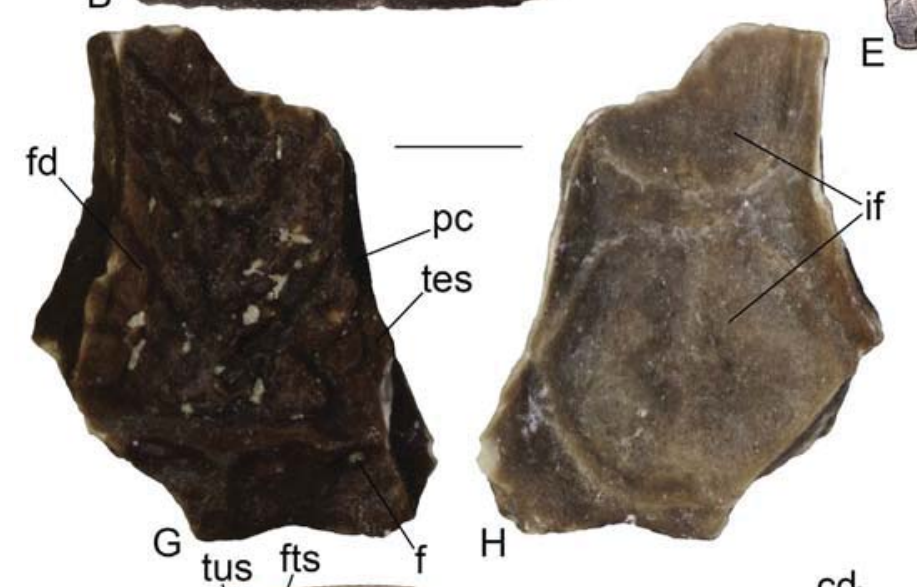

$\mathrm{E}$
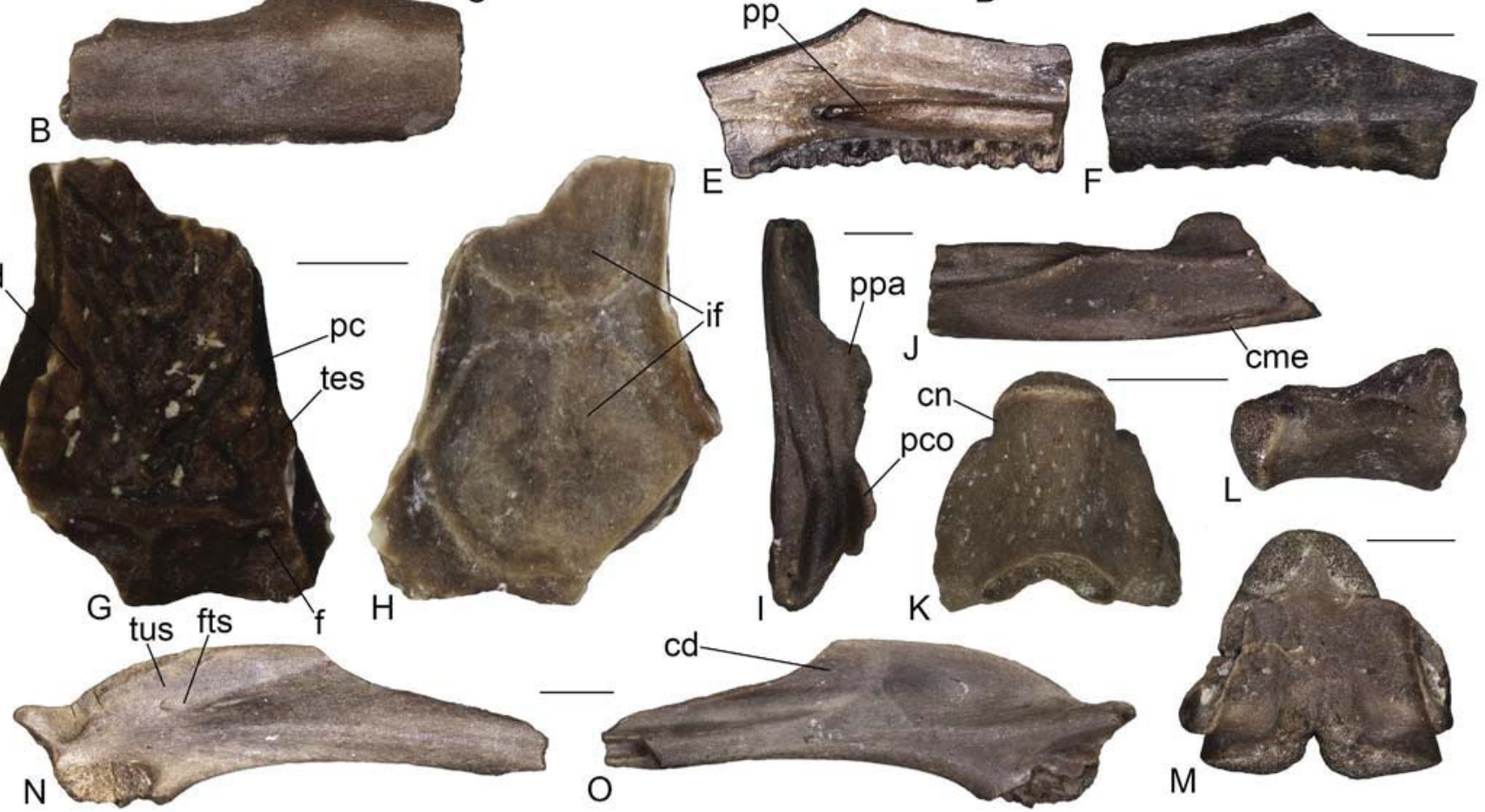

$\mathrm{M}$

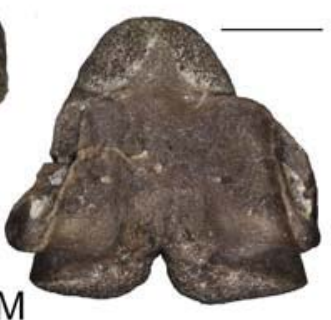

Figure 3. Latonia cf. gigantea from Karydia-3: left maxilla (AMPG KR3 005) in medial (A) and lateral (B) views; left maxilla (AMPG KR3 015) in medial (C) and lateral (D) views; left maxilla (AMPG KR3 016) in medial (E) and lateral (F) views; frontoparietal (AMPG KR3 038) in dorsal (G) in ventral (H) views; left praearticular in dorsal (I) and lateral $(\mathrm{J})$ views; trunk vertebra (AMPG KR3 033) in ventral (K) and left lateral (L) views; sacral vertebra (AMPG KR3 032) in dorsal view (M); right ilium (AMPG KR3 011) in lateral $(\mathrm{N})$ and medial $(\mathrm{O})$ views.

Scale bars = $1 \mathrm{~mm}$. Abbreviations: cd, crista dorsalis; cme, crista mandibulae externa; $\mathrm{cn}$, condylar neck; f, foramen; $\mathrm{fd}$, facies dorsalis; fts, fossula tuberis superioris; if, incrassatio frontoparietalis; la, lamina anterior; lh, lamina horizontalis; or, ornamentation; pc, pars contacta; pco, processus coronoideus; pd, posterior depression; pp, processus pterygoideus; ppa, processus paracoronoideus; tes, tectum supraorbitale; tus, tuber superior.

appears to be developed only as a rather low lamina by each side of the posterior end of the facies dorsalis. The latter is covered by a moderate dermal ornamentation consisting of low tubercles and grooves. The degree of development of the ornamentation tends to fade both anteriorly and towards the lateral sides. Posteriorly to the facies dorsalis, a rather low longitudinal ridge is present in the middle of the smooth posterior area of the dorsal surface of the frontoparietal. By the end of this ridge, a processus posterior is not developed. A sharper ridge runs also at the middle of the dorsal surface of the preserved portion of the processus paraoccipitalis. Medially to the contact between the facies dorsalis and the latter ridge, a small foramen is visible that might represent the opening for the occipital artery. On the lateral sides, the pars contacta is laminar and ventrolaterally extended. On the ventral surface, the incrassatio frontoparietalis is clearly divided into an anterior and a posterior portion, even though the margins of these two portions are poorly marked. Both portions are large. Only the posterior portion of the incrassatio is completely preserved, showing a circular shape. The surface of the incrassatio frontoparietalis is smooth.
Praearticulars. These elements are rather small-sized (Figure $3(\mathrm{I})-(\mathrm{J}))$. They have a slender and horizontal processus paracoronoideus followed posteriorly by a slender and vertically oriented processus coronoideus. The latter is completely damaged in AMPG KR3 029, but its base is visible, attesting its original presence. The rather narrow sulcus pro cartilago Meckeli is rather shallow anteriorly, but it deepens strongly by the processus coronoideus. The lateral surface displays a large and deep depression, marked ventrally by a sharp crista mandibulae externa. The extremitas spatulata is missing.

Trunk vertebrae. They are small sized and represented only by the centrum (Figure 3(K)-(L)). The centrum is ophisthocoelous and displays a distinct condylar neck. The shape of the centrum is rather cylindrical, but a slight ventral concavity is visible in lateral view. The concavity is more evident in AMPG KR3 033, however, it is distinctly smaller in AMPG KR3 031. Small portions of the rather thin lateral walls of the neural arch are also preserved in both specimens.

Sacral vertebra. This element also preserves only the vertebral centrum (Figure 3(M)). It has an anterior condyle and two 
posterior condyles. Its size is comparable with the largest trunk vertebra. The condyles are dorsoventrally compressed and the centrum is ventrally flattened.

Ilia. These elements are rather small. AMPG KR3 011 preserves most of the shaft, but only a small part of the acetabular portion (Figure $3(\mathrm{~N})-(\mathrm{O})$ ). A moderately high crista dorsalis is present. Its anterior half is missing, but the preserved portion seems to display a medial bending anteriorly. The posterior end of the crista is characterised by a poorly marked and anteroposteriorly elongated tuber superior. A shallow fossula tuberis superioris (sensu Roček 1994) is present, housing a small foramen. The supracetabular fossa is deep. Most of the acetabulum is missing, but its anterior margin was strongly raised laterally and seems to have been prominent. Both the partes ascendens and descendens are almost completely broken off, but a deep interiliac groove is still visible in medial view. The other specimens are less well-preserved, but their morphology is fully comparable with that of AMPG KR3 011.

Remarks. Maxillae with a long and slender processus pterygoideus and a medial depressed area in the posterior portion, together with prearticulars possessing a processus paracoronoideus associated to the processus coronoideus clearly attest the presence of the discoglossine Latonia in Karydia-3 (Roček 1994, 2013). Other, similar-sized remains showing discoglossine features, such as opisthocoelous vertebrae and ilia with a medially-bending crista dorsalis and an interiliac groove, can also be assigned to the same taxon (Roček 1994, 2013; Bailon 1999). The attribution of the frontoparietal from KR3 to Latonia is supported by its unpaired nature and the split incrassatio frontoparietalis with a circular posterior portion, but the presence of a foramen for the occipital artery is rather unusual, since this feature is reported to be absent in representatives of the genus (Roček 1994, 2013; Rage and Hossini 2000). Nevertheless, the general morphology of the frontoparietal is fully comparable with early ontogenetic stages of Latonia gigantea, as described by Roček (1994) and Rage and Hossini (2000). In particular, the most significant similarities are the narrow facies dorsalis if compared with the pars contacta, the laminar and ventrolaterally-developed pars contacta, and the poorly-marked margins of the incrassatio frontoparietalis. The small size of the specimen also agrees with a juvenile condition, even though the ornamentation, consisting of low tubercles instead of pits and ridges, might suggest it was not a postmetamorphic individual, but rather a subadult (Roček 1994, 2013). The identification as a rather young specimen of L. gigantea might be also valid for at least the maxilla AMPG KR3 015, based on the presence of low developed tubercles on the processus zygomaticomaxillaris and the absence of the ridge marking the anterior part of the medial depression in adults (Roček 1994, 2013). Given the small size and the overall similar morphology shown by the other specimens, it seems possible that all discoglossine fossils from Karydia-3 might belong to young individuals of L. gigantea. Nevertheless, the presence of a foramen for the occipital artery on the frontoparietal is rather puzzling, and, as such, the identification is here considered only tentative.

cf. Latonia sp. (Figure 4A-G)

Material. AL1a: an atlas (UU AL 3593). AL1980NQ: three maxillae (UU AL 3552, UU AL 3555, and UU AL 3596), and a right ilium (UU AL 3598).

\section{Description}

Maxillae. All maxillae from Aliveri are represented by small fragments, the largest one (UU AL 3552) being roughly $4 \mathrm{~mm}$ in total length (Figure 4(A)-(B)). They preserve only part of the middle portion of the bone. In medial view, a mediolaterally short and medially convex lamina horizontalis is visible, marking the crista dentalis dorsally. The latter bears pleurodont, closely-spaced, and cylindrical teeth, of which none is completely preserved. The number of preserved tooth-positions is at least 12 in UU AL 3552. The dorsal surface of the lamina horizontalis is marked by a narrow and rather deep groove. The preserved portion of the lateral surface is smooth in all specimens. Certain morphological features, such as the shape of the lamina horizontalis, the tooth morphology, and the smooth lateral surface resemble the specimens from Karydia-3, described above as Latonia cf. gigantea.

Atlas. The atlas from Aliveri preserves only the vertebral centrum (Figure $4(\mathrm{C})-(\mathrm{E})$ ). It is small-sized, strongly dorso-ventrally
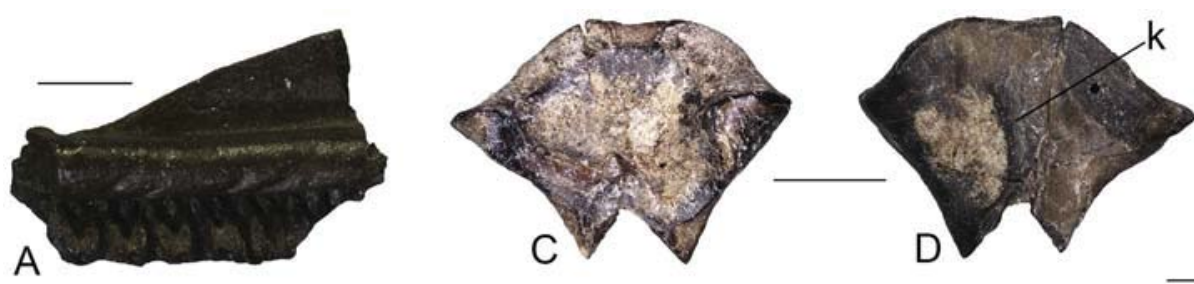

E
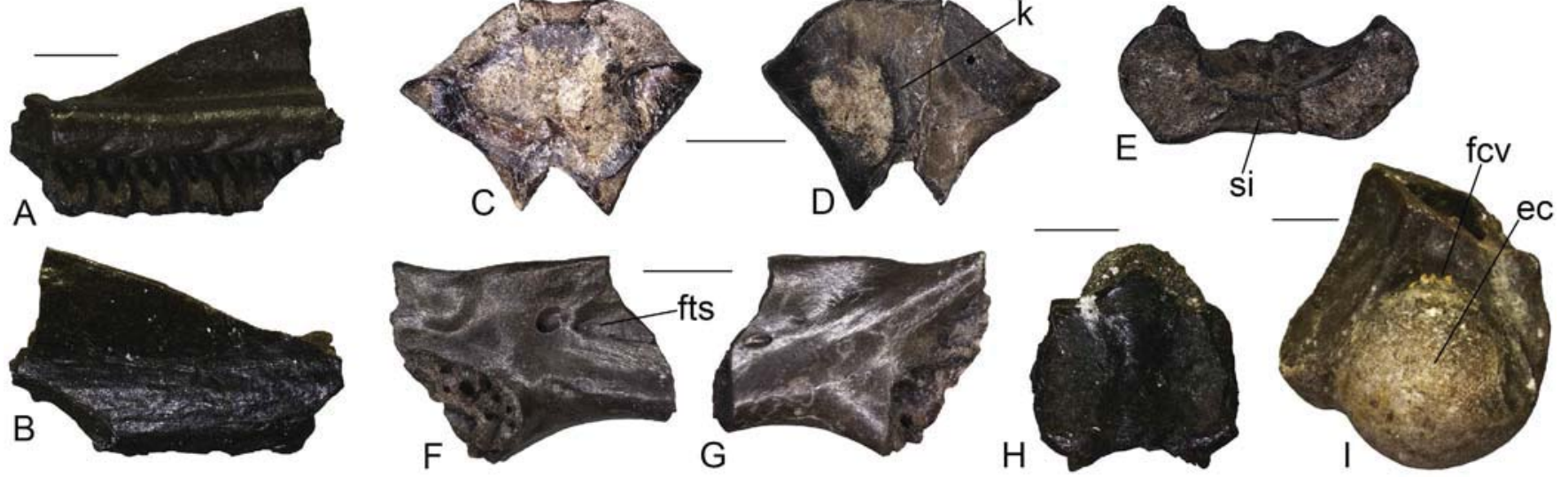

Figure 4. cf. Latonia sp. from Aliveri (A-G): left maxilla (UU AL 3552) in medial (A) and lateral (B) views; atlas (UU AL 3593) in dorsal (C), ventral (D) and anterior (E) views; right ilium (UU AL 3598) in lateral (F) and medial (G) views. Anura indet. from Aliveri (H): trunk vertebra (UU AL 3553) in dorsal view (H). Anura indet. from Karydia-2 (I): left humerus (UU KR2 5015) in ventral view (I).

Scale bars = 1 mm. Abbreviations: ec, eminentia capitata; fcv, fossa cubitalis ventralis; fts, fossula tuberis superioris; $k$, keel; si, spatium interglenoidale. 
compressed, and has a subcircular posterior cotyle. Anteriorly, two kidney-shaped cotyles are present. They are moderately large and dorsoventrally inclined in anterior view. They are not in contact, since a moderately wide spatium interglenoidale separates them in the middle. A robust keel is visible on the ventral surface of the centrum.

Ilium. The small ilium from Aliveri preserves part of the acetabular portion and the base of the shaft (Figure $4(\mathrm{~F})-(\mathrm{G})$ ). On the dorsal margin, part of a rather poorly marked tuber superior is preserved. In life, it was probably confluent with a crista dorsalis, which is now missing. Even though the pars ascendens is missing, the angle between the latter and the tuber superior is rather obtuse in lateral view. Two foramina, a strongly larger posterior one and a rather small anterior one, are visible on the lateral surface of the bone; they are located in a rather shallow fossula tuberis superioris. There is no supracetabular fossa. The acetabulum is strongly eroded, but its anteroventral margin is prominent laterally. The preacetabular area is not expanded. Because the ileoischiadic junction is not preserved, it is not possible to discern whether the interiliac tubercle and groove were present.

Remarks. In spite of their fragmentary nature, a clear similarity of these specimens is recognizable with Latonia. In particular, the Aliveri specimens resemble Latonia in the shape of the lamina horizontalis of the maxillae, the ventral keel, the dorsoventrally inclined and medially separated anterior cotyles of the atlas, the poorly-marked tuber superior, the obtuse angle between the tuber and the pars ascendens, and the presence of a fossula tuberis superioris with foramina located into the latter on the ilium (Roček 1994, 2013; Biton et al. 2016). Among discoglossine alytids, a certain similarity is apparent in at least some bones between Latonia and Discoglossus (e.g. the ilium; Roček 1994; Biton et al. 2016), but the Aliveri fossils cannot be assigned to the latter genus due to the fact that the maxillae bear a more slender lamina horizontalis and the ilia have a more prominent tuber superior forming a less obtuse angle with the pars ascendens (Roček 1994; Bailon 1999; Biton et al. 2016). Due to the poor preservational condition and the scarcity of the fossil material, we here prefer to identify these specimens only tentatively, avoiding also any specific identification, pending the possible discovery of new remains in the future.

Anura indet. (Figure $4 \mathrm{H}-\mathrm{I}$ )

Material. ALla: an ilium (UU AL 3595), a trunk vertebra (UU AL 3553), and three indeterminate elements (UU AL 3554, UU AL 3594). AL1980NQ: an indeterminate element (UU AL 3597). KR2: a left humerus (UU KR2 5015) and a fragment of radioulna (UU KR2 5016). KR3: a premaxilla (AMPG KR3 003), an ilium (AMPG KR3 024), and eight phalanxes (AMPG KR3 006 and AMPG KR3 023).

Description and remarks. These anuran remains from Aliveri are too fragmentary to allow for rigorous identification. Among them, the sole known, small (roughly $2.7 \mathrm{~mm}$ long) trunk vertebra (UU AL 3553) could probably belong to the above described cf. Latonia sp. on the basis of the cylindrical shape of the centrum. However, the specimen is incomplete and only the cylindrical vertebral centrum is preserved (Figure $4(\mathrm{H})$ ). It displays a cotyle and a condyle, both circular in shape, but since a clear condylar neck is not recognizable, it is not possible to state whether the vertebra was opisthocoelous or procoelous in life. As such, we refrain from formally referring it to cf. Latonia and treat this vertebra as an indeterminate anuran. Furthermore, the recognition of the condylar neck is also hindered by a distinct lateral development of the condyle on both sides, possibly indicating a rather high degree of lateral movement of the articulating vertebrae. The respective material from Karydia- 2 is relatively better preserved: a medium-sized humerus preserving only the distal epiphysis and a small and very poorly preserved fragment of a radioulna can be assigned only to an indeterminate anuran. The humerus displays a sphaerical eminentia capitata and a moderately deep fossa cubitalis ventralis (Figure 4(I)). The epicondylus ulnaris is robustly built. The epicondylus radialis, on the other hand, is rather small and displays a distinct tubercle on the ventral surface, which is separated from the eminentia capitata by a narrow groove. The bases of both the cristae lateralis and medialis are well developed. On the dorsal surface, the olecranon scar is not recognizable. The fossil remains from Karydia-3 are fragmentary and lack diagnostic characters to the family level, and as such, are here also identified as indeterminate anurans.

Reptilia Laurenti, 1768

Testudines Batsch, 1788

Testudines indet. (Figure 5)

Material. AL2: two shell fragments (UU AL 3504-UU AL 3505). KR2: three shell fragments (UU KR2 5001-UU KR2 5003).

Description. The two fragments from Aliveri can be joined together in a single, larger fragment (about one square $\mathrm{cm}$ ) that comes from a chelonian shell (Figure $5(\mathrm{~A})-(\mathrm{F})$ ). This identification is supported by the presence of a smooth visceral and a finely vermiculated external surface characterised by a scute sulcus. Moreover, two of the edges of this larger fragment host the typical chelonian sutures. The three small fragments from Karydia are characterised by being thin $(2-4 \mathrm{~mm})$ and provided with a rather smooth (visceral) surface and a slightly rough opposite (external) surface (Figure 5(G)-(M)). With the exception of UU KR2 5002, the fragments show a sutural surface on at least one edge. Growth marks are visible on the slightly vermicular external surface of UU KR2 5001. UU KR2 5002 hosts a straight sulcus on the dorsal surface and shows a very modest convexity on its ventral surface, suggesting that this fragment could originate from a costal bone. A rather thin, elongated tubercle, associated with the presence of sutures at three edges, could indicate that UU KR2 5003 is a small fragmentary costal bone as well.

Remarks. The material from Aliveri and Karydia is too fragmentary to permit a precise identification of the shell elements. Four clades of non-marine turtles are known from the early Miocene of this region: pan-testudinoids (sensu Joyce et al. 2004), podocnemidoideans, pan-chelydrids, and pan-trionychids (Georgalis and Kear 2013; Georgalis et al. 2013; Joyce 2016; Georgalis and Joyce 2017). The absence of a sculpturing pattern clearly denotes that the material described herein does not pertain to pan-trionychids (Georgalis and Joyce 2017). The general morphology is reminiscent of pan-testudinoids but podocnemidoidean and chelydrid affinities cannot be excluded. Therefore, the material from both localities is herein referred to Testudines indet.

Crocodylia Gmelin, 1789

Crocodylia indet. (Figure 6) 
Material. AL1a: six isolated teeth (UU AL 3536-UU AL 3541). AL1b: ten isolated teeth (UU AL 3576-UU AL 3585). AL1980NQ: an isolated tooth (UU AL 3556).

Description. All teeth from Aliveri share the following characters: small size (the largest, UU AL 3539, is $2.5 \mathrm{~cm}$ long), unserrated mesiodistal carinae, rather acute shape (UU AL 3536 is slightly more massive than the others), lingual surface slightly concave, labial surface slightly convex, smooth lingual and labial surfaces, absence of root, and a concave base (Figure 6). UU AL 3537 is the tip of a slightly larger tooth, but shares with the other specimens all the characters available on the preserved portion of the tooth. Remarks. Isolated crocodylian teeth are not diagnostic at a lower taxonomic level (Delfino et al. 2007; Čerňanský et al. 2012; Georgalis, Villa, Vlachos et al. 2016) and therefore the Aliveri material can only be referred to Crocodylia indet. The small size of the teeth and the fact that their root was likely reabsorbed could indicate that they were shed by small individuals (there is no clear evidence of breakage of the root; Frey and Monninger 2010).

Squamata Oppel, 1811

Acrodonta Cope, 1864

Chamaeleonidae Gray, 1825

Chamaeleo Laurenti, 1768

Chamaeleo andrusovi Čerňanský, 2010
Chamaeleo cf. andrusovi

Material. AL1a: a skull roofing bone (UU AL 3501).

Remarks. The chamaeleonids from Aliveri were extensively described by Georgalis, Villa and Delfino (2016) and the reader is referred to that paper for further details. Although they probably all pertain to the same species, only the skull roofing bone possessed enough diagnostic characters for a species determination and was accordingly referred to Chamaeleo cf. andrusovi, whereas the tooth bearing bones were simply considered as indeterminate chamaeleonids. No further chamaeleonid material has been recovered from Aliveri.

Chamaeleonidae indet.

Material. AL1b: a fragment of tooth-bearing bone (UU AL 3502); AL1980NQ: a fragment of tooth-bearing bone (UU AL 3503).

Remarks. See Chamaeleo andrusovi above.

Scincomorpha Camp, 1923 (sensu Estes et al. 1988)

Lacertidae Oppel, 1811

Lacertidae indet. (Figure 7A-G)

Material. AL1a: a fragment of tooth-bearing bone (UU AL 3520). AL1b: a dentary (UU AL 3586) and five fragments of tooth-bearing bones (UU AL 3557-UU AL 3561). AL1980NQ: a fragment of tooth-bearing bone (UU AL 3542). KR3: two maxillae (AMPG KR3 017-AMPG KR3 018) and an isolated tooth (AMPG KR3 007).

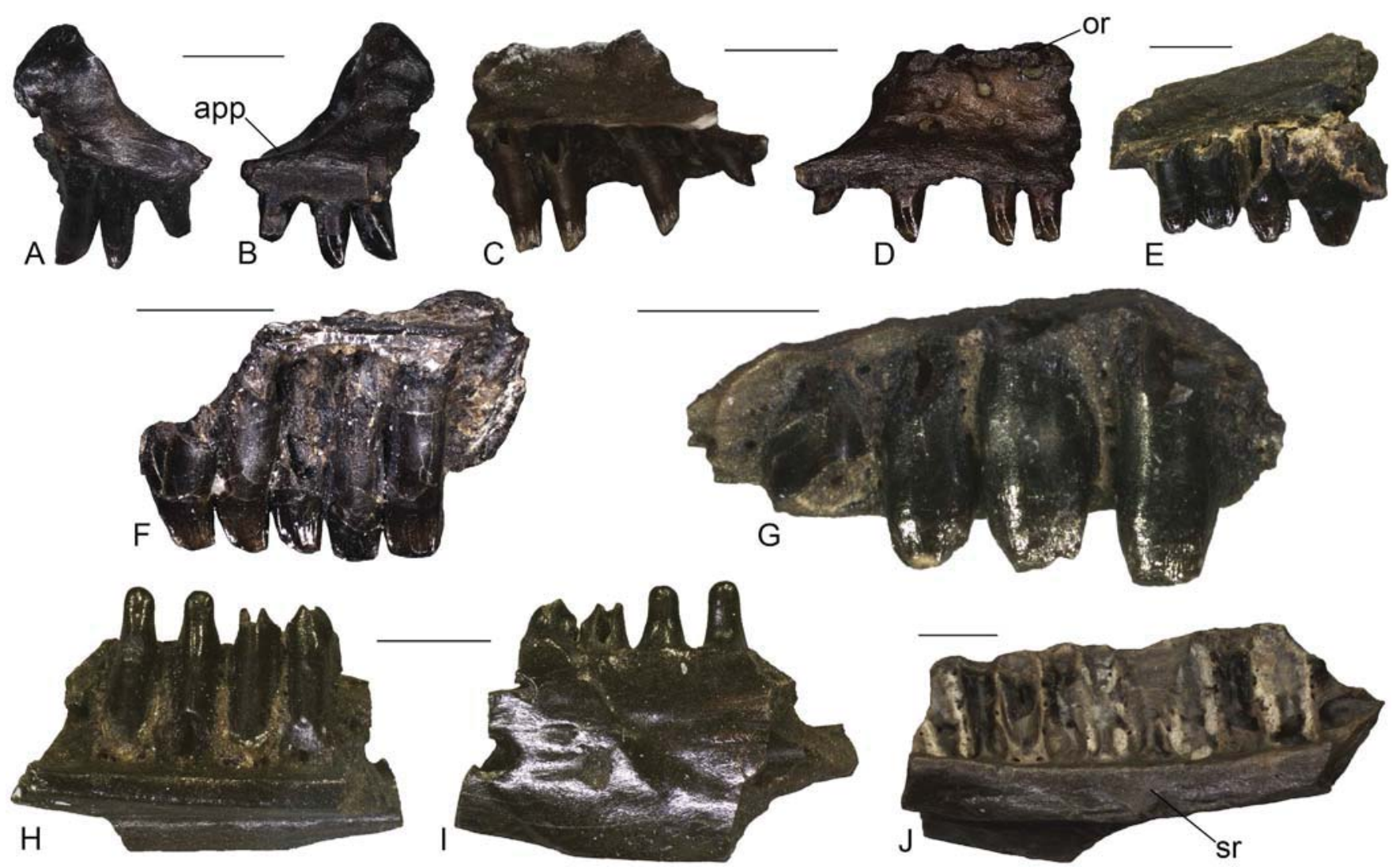

Figure 7. Lacertidae indet. from Karydia-3 (A-D): left maxilla (AMPG KR3 017) in medial (A) and lateral (B) views; left maxilla (AMPG KR3 018) in medial (C) and lateral (D) views. Lacertidae indet. from Aliveri (E-G): fragment of tooth-bearing bone (UU AL 3557) in medial view (E); fragment of tooth-bearing bone (UU AL 3558 ) in medial view (F); fragment of tooth-bearing bone (UU AL 3559) in medial view (G). Scincomorpha indet. from Aliveri (H-I): left dentary (UU AL 3519) in medial (H) and lateral (I) views; Scincomorpha indet. from Karydia-3 (J): right dentary (AMPG KR3 010) in medial view (J).

Scale bars $=1 \mathrm{~mm}$. Abbreviations: app, anterior premaxillary process; or, ornamentation; sr, subdental ridge. 


\section{Description.}

Maxillae. The lacertid maxillae from KR3 are rather small, fragmentary, and represent only the anterior end of the bone (Figure 7(A)-(D)). The anterior premaxillary process has short anterolateral and anteromedial processes separated by a shallow concavity. Dorsally, the vomeronasal foramen is moderately large and housed in a shallow concave area. It seems that a lappet is absent on the dorsal surface of the anteromedial process. In spite of the strong fragmentary nature of the specimens, a dermal ornamentation appears to be present on the lateral surface of the facial process, at least in AMPG KR3 018 (Figure 7(D)). Ventrally to the ornamentation, some ventrolateral foramina are present. Teeth are pleurodont, cylindrical, narrow, and closely spaced. AMPG KR3 017 preserves three teeth, whereas AMPG KR3 018 has four preserved teeth plus two empty tooth positions. Only one tooth preserves a monocuspid crown in the former specimen, whereas a bicuspid condition is recognizable in all teeth of the latter except for the anteriormost one in which the crown is not preserved.

Dentary. The dentary UU AL 3586 preserves only part of the middle portion of the bone. It is $4 \mathrm{~mm}$ in length. The Meckelian fossa is wide and opens medially. Teeth are pleurodont but no one is preserved. A moderately slender subdental ridge is present. The ventral margin is distinctly convex in medial view. The labial surface is smooth, though a light roughness seems to be present, however, this could be due to taphonomical reasons. Two mental foramina are present.

Tooth bearing elements. The fragments of indeterminate tooth bearing bones bear pleurodont, cylindrical, mono-, bi- and tricuspid teeth, which generally show wear (Figure $7(\mathrm{E})-(\mathrm{G})$ ). Teeth of the largest specimens (UU AL 3557 and UU AL 3559) are hypertrophied.

Isolated tooth. AMPG KR3 007 is a single pleurodont and cylindrical tooth. It has a bicuspid crown, with a large main cusp and a smaller accessory cusp.

Remarks. The heterodont dentition of these tooth bearing bones from Aliveri is indicative of lacertid affinities (Bailon 1991), though they cannot be more precisely identified due to their poor preservational condition. In spite of the absence of well-preserved teeth, the Aliveri dentary is also assigned to the same taxon because of the convex ventral margin, which is also found in lacertids (AV, pers. obs.). It should be noted that the morphology of the hypertrophied teeth in UU AL 3557 and UU AL 3559 could be reminiscent of certain amblyodont lacertids from the Paleogene and early Neogene of western Europe (Augé 2005), but the Aliveri lizards cannot be attributed to the latter forms, as in amblyodont lizards, the crown is blunt and rounded, and as such, the cusps should be either totally absent or, in some cases, poorly marked.

The overall morphology of the KR3 specimens is consistent with an identification as undetermined lacertids (Bailon 1991; Barahona 1996). Similarly to the Aliveri lacertids, it is difficult to clearly identify the remains at a specific or even generic level, due to their poor preservational status. Nevertheless, their size would suggest the presence of a small-sized taxon in Karydia-3. The presence of the distinct dermal ornamentation on AMPG KR3 018 could testify that, at least this specimen pertains to an adult, and not to a juvenile of a larger species.

Scincomorpha indet. (Figure $7(\mathrm{H})-(\mathrm{J})$ )
Material. AL1a: three dentaries (UU AL 3519, UU AL 3521, and UU AL 3524). AL1980NQ: a dentary (UU AL 3549). KR3: a dentary (AMPG KR3 010).

Description. The specimens from Aliveri are poorly preserved fragments of dentaries, with a total length of $3.5 \mathrm{~mm}$ (UU AL 3519), slightly less than $5 \mathrm{~mm}$ (UU AL 3521), roughly $2.5 \mathrm{~mm}$ (UU AL 3524), and roughly $3 \mathrm{~mm}$ (UU AL 3549) respectively. In medial view, the dentaries display a slender (UU AL 3519) or moderately thick (all other specimens) subdental ridge and a medially open Meckelian fossa. The ventral margin of the bone is missing in all specimens except for UU AL 3549, in which it appears rather straight. At least four (in UU AL 3519), seven (in UU AL 3524) and ten (in UU AL 3521) tooth positions are recognizable, but teeth are preserved only in UU AL 3519 (all four of them) and 3524 (a single one). Teeth appear to have been slender, cylindrical and pleurodont. Teeth of UU AL 3519 are strongly eroded at the tip, but appear to have a peculiar, rather abrupt constriction towards the dorsal level of the dentary (Figure $7(\mathrm{H})-(\mathrm{I}))$, however, it cannot be ascertained whether this was a true feature in life or is simply an artifact of taphonomy and preservation. The preserved tooth of UU AL 3524 is monocuspid. UU AL 3549 preserves the anterior end, displaying a narrow and subhorizontal mandibular symphysis. The lateral surface is smooth, carrying some mental foramina, in all specimens except for UU AL 3519, where it is slightly rugged.

The dentary fragment from Karydia-3 (AMPG KR3 010) displays a moderately thick subdental ridge on its medial side (Figure 7(J)). The Meckel's groove is open and narrows anteriorly. The ventral margin of the fragment is mostly broken off. The alveolar portion carries 10 tooth positions, but the teeth are not preserved. Nevertheless, they were pleurodont, closely spaced and rather narrow. The lateral surface is smooth, with at least four mental foramina. The total length of the fragment is $6 \mathrm{~mm}$.

Remarks. The presence of a subdental ridge on the medial side discriminates dentaries of scincomorph lizards from those of anguimorphs, but it is also present in iguanians and gekkotans (Evans 2008). Nevertheless, the combination of an open Meckel's groove and the pleurodont dentition allow us to exclude an attribution of these dentaries to the latter two groups, rather favouring a scincomorph (sensu Estes et al. 1988) assignment. The preservational condition of the specimens from Aliveri hinders a taxonomic attribution at the family level, but the presence of more than one taxon might be suggested by the difference in the smoothness of the lateral surface of the dentaries. Regarding the Karydia-3 material, if our identification of the other scincomorphs described above as adults of a small lacertid is correct, then the larger size of this dentary might suggest the presence of a second, though still indeterminate, scincomorph taxon in that locality.

Anguimorpha Fürbringer, 1900

Anguidae Gray, 1825

Anguinae Gray, 1825

Ophisaurus Daudin, 1803

cf. Ophisaurus sp. (Figure 8A-D)

Material. KR3: a tooth (AMPG KR3 035) and a trunk vertebra (AMPG KR3 034).

Description.

Tooth. The isolated tooth is rather small and pointed, even though the tip is broken (Figure $8(\mathrm{~A})$ ). It has a conical, roughly 

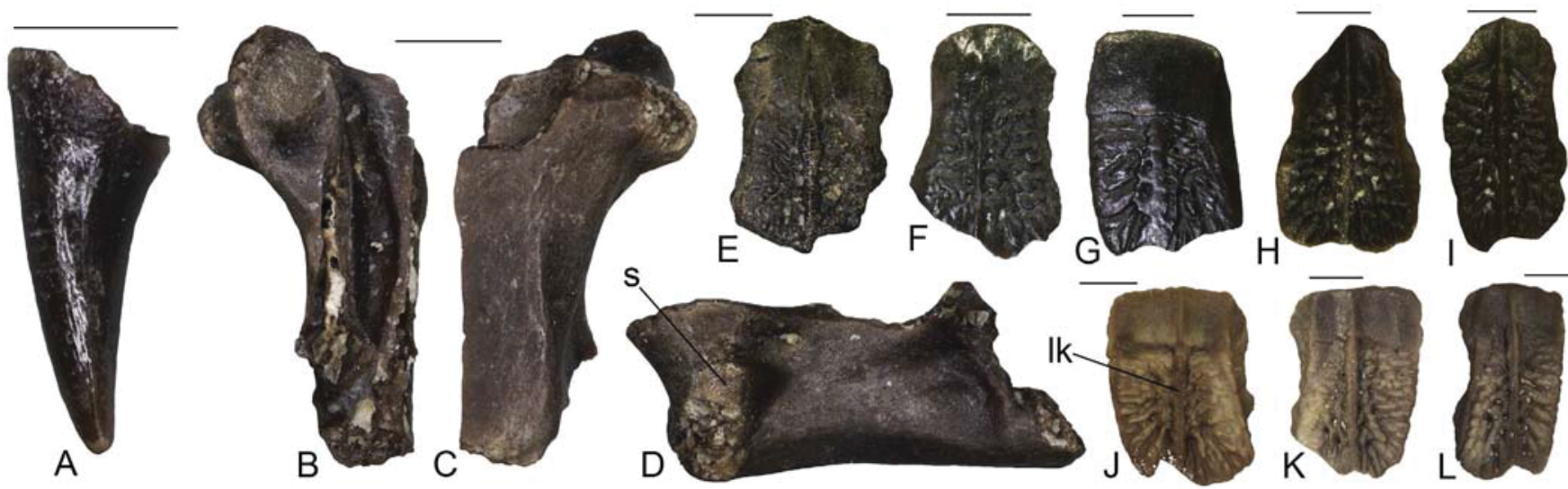

Figure 8. cf. Ophisaurus sp. from Karydia-3 (A-D): isolated tooth (AMPG KR3 035) in medial view (A); trunk vertebra (AMPG KR3 034) in dorsal (B), ventral (C), and left lateral (D) views. non-Anguis Anguinae indet. from Aliveri (E-G): osteoderm (UU AL 3506) in external view (E); osteoderm (UU AL 3516) in external view (F); osteoderm (UU AL 3545) in external view (G); non-Anguis Anguinae indet. from Karydia-2 (H-I): osteoderm (UU KR2 5007) in external view (H); osteoderm (UU KR2 5008) in external view (I); non-Anguis Anguinae indet. from Karydia-3 (J-L): osteoderm (AMPG KR3 002) in external view (J); osteoderm (AMPG KR3 039) in external view (K); osteoderm (AMPG KR3 040) in external view (L).

Scale bars $=1 \mathrm{~mm}$, except for $\mathrm{A}$, in which it is $0.5 \mathrm{~mm}$. Abbreviations: Ik, longitudinal keel; s, synapophysis.

canine shape. The tooth base is not swollen and the apex is not curved. No striae are present. There are small and sharp carinae both anteriorly and posteriorly.

Trunk vertebra. The vertebra is procoelous and rather fragmentary as only the left side is preserved (Figure 8(B)-(D)). The neural arch is completely missing, as well as the posterior condyle. The preserved portion of the centrum is roughly $4 \mathrm{~mm}$ long. The centrum is dorsoventrally compressed and has a flat ventral surface. Despite the absence of the condyle, a precondylar constriction does not seem to be present. The left lateral margin of the centrum is oblique and slightly concave in ventral view. The left synapophysisis is eroded, but it is distinctly dorsoventrally elongated. The left prezygapophysis is subelliptical and slightly dorsally tilted.

Remarks. The morphology of both AMPG KR3 034 and AMPG KR3 035 is reminiscent of that of Ophisaurus. As far as the vertebra is concerned, its attribution to Ophisaurus is supported by the compressed centrum with no precondylar constriction, an oblique and concave lateral margin, and a flat ventral surface (Klembara 1981; Estes 1983). The isolated tooth, on the other hand, resembles Ophisaurus in its conical shape and the absence of a strong curvature (Klembara et al. 2014). Despite the fact that extant species of Ophisaurus are reported to have striated tooth crowns, fossil remains with unstriated Ophisauruslike dentition are also known (e.g. Anguine morphotype I from Merkur-Nord; Klembara 2015). An attribution of these two fossils from KR3 to Ophisaurus seems therefore possible, but due to scarcity of material and its poor preservational status we here prefer to treat this identification with caution.

non-Anguis Anguinae indet. (Figure 8E-L)

Material. AL1a: 60 osteoderms (UU AL 3506-UU AL 3518). AL1b: 14 osteoderms (UU AL 3562-UU AL 3575). AL1980NQ: 22 osteoderms (UU AL 3543-UU AL 3548). KR2: seven osteoderms (UU KR2 5006-UU KR2 5013). KR3: 11 osteoderms (AMPG KR3 001, AMPG KR3 002, AMPG KR3 008, AMPG KR3 019, AMPG KR3 039-AMPG KR3 043, AMPG KR3 046, AMPG KR3 047, AMPG KR3 056, and AMPG KR3 057).
Description. Osteoderms from Aliveri are small, but rather thick and robust (Figure 8(E)-(G)). They show an external surface with a smooth gliding portion, a vermicular ornamentation and a well-developed longitudinal keel on the external surface. The most well preserved ones are subrectangular in shape.

Osteoderms from Karydia-2 are similar to those from Aliveri. They are small, but robustly-built (Figure 8(H)-(I)). The external surface shows a smooth gliding portion, a vermicular ornamentation on the rest of the surface, and a well-evident longitudinal keel. Osteoderms from Karydia-3 are small and subrectangular in shape (Figure $8(\mathrm{~J})-(\mathrm{L}))$. They display a vermicular ornamentation and, with the sole exception of AMPG KR3 008, a longitudinal keel on the external surface. Similar to the osteoderms from Aliveri and Karydia-2, they also show a smooth gliding portion in their external surface.

Remarks. The presence of anguids in Aliveri and Karydia is testified by a large number of osteoderms showing the typical vermicular ornamentation on the external surface. The thickness, the presence of a keel, and the subrectangular shape are found in non-Anguis anguine taxa (i.e. either Pseudopus or Ophisaurus), in contrast to smaller, rounded and unkeeled osteoderms in Anguis (Delfino et al. 2011). Regarding the osteoderms from KR3, it is most probable that they pertain to cf. Ophisaurus sp. that was described above from that locality.

Serpentes Linnaeus, 1758

Alethinophidia Nopcsa, 1923

Colubridae Oppel, 1811

Colubridae indet. (Figure 9)

Material. AL1980NQ: an anterior trunk vertebra (UU AL 3590). KR2: a posterior trunk vertebra (UU KR2 5018), a posterior trunk vertebra (UU KR2 5019), a caudal vertebra (UU KR2 5025), and a fragmentary vertebra (UU KR2 5020). KR3: a fragment of a trunk vertebra (AMPG KR3 020).

Description. The trunk vertebrae from both Aliveri and Karydia are incomplete, lacking zygapophyses and synapophyses. The best-preserved specimen, a posterior trunk vertebra (UU KR2 

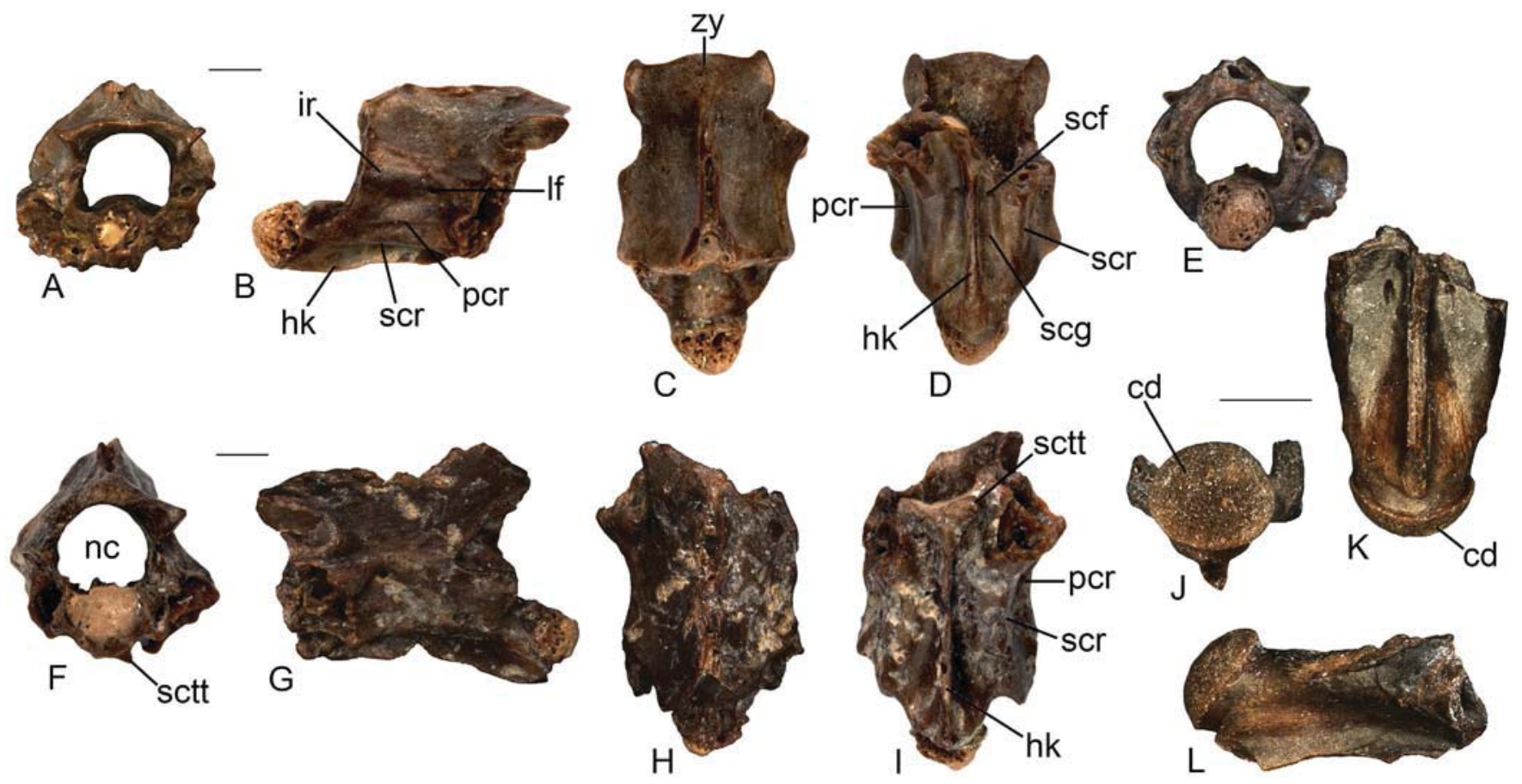

Figure 9. Colubridae indet. from Karydia-2 (A-l): posterior trunk vertebra (UU KR2 5018) in anterior (A), right lateral (B), dorsal (C), ventral (D), and posterior (E) views; posterior trunk vertebra (UU KR2 5019) in anterior (F), left lateral (G), dorsal (H), and ventral (I) views; Colubridae indet. from Aliveri (J-L): anterior trunk vertebra (UU AL $3590)$ in posterior $(\mathrm{J})$, ventral $(\mathrm{K})$, and right lateral $(\mathrm{L})$ views.

Scale bars $=1 \mathrm{~mm}$. Abbreviations: cd, condyle; hk, haemal keel; ir, interzygapophyseal ridge; If, lateral foramen; $\mathrm{nc}$, neural canal; pcr, paracentral ridge; scf, subcentral foramen; scg, subcentral groove; scr, subcentral ridge; sctt, subcotylar tubercle; zy, zygosphene.

5018), possesses a relatively small zygosphenal facet of oval to sigmoid outline in lateral view (Figure 9(A)-(E)). A large lateral foramen is situated below the rather sharp interzygapophyseal ridge. Its orifice occurs in the vicinity of the dorsal margin of the rather deep and anteroposteriorly slightly enlarged wide depression. The ventral margin of the depression is bordered by a peculiar, distinct sharp crest, which extends from the caudal margin of the unpreserved synapophysis as far as the two thirds of the length of the subcentral ridge. This highly distinct ridge that lies between and almost parallel to the interzygapophyseal and the subcentral ridges is herein termed as 'paracentral ridge'. The subcentral ridges are rather prominent. They are straight and extend as far as the posterior border of the pedicle. Due to the incomplete nature of the specimen, it cannot be certain whether the vertebra possessed a haemal keel or a hypapophysis, although the former structure (haemal keel) seems to have been more probable. The rather narrow haemal keel (or short hypapophysis) is broken off close to its base. In dorsal view, the zygosphene has distinct lateral lobes and a wide medial lobe. The base of the neural spine rises rather anteriorly, at about half of the length of the zygosphenal facet. In ventral view, the subcentral grooves are rather deep. The subcentral foramina are rather large and are situated at the base of the significantly thin haemal keel/ hypapophysis. Their orifices are directed anteriorly. The posterior section of the haemal keel/hypapophysis is situated on a triangular-shaped elevation, this feature providing relative support for the presence of a haemal keel instead of a hypapophysis. The anterior portion of the haemal keel/hypapophysis of the second posterior trunk vertebra from Karydia (UU KR2 5019) is triangular, with distinct subcotylar tubercles, though only the left one is preserved (Figure 9(F)-(I)). In anterior view, the zygosphenal lip is vaulted dorsally. The neural canal is rounded with short but distinct lateral sinuses. The cotyle, partially preserved in one vertebra, seems to have been most probably circular. UU AL 3590 is an anterior trunk vertebra and is rather incomplete (Figure 9(J)-(L)). Similarly to UU KR2 5018, it is also characterised by a large depth of the subcentral grooves.

Remarks. The vertebrae can be attributed to Colubridae on the basis of their gracile structure, their longer than wide centrum, the narrow haemal keel (or hypapophysis), the distinct subcentral ridges and subcentral grooves, and the gracile zygosphene (Rage 1984; Szyndlar 1984, 1991a, 1991b; LaDuke 1991; Holman 2000). This taxonomic attribution is further supported by the fact that, although the anterior margin of all vertebrae is damaged, the distinct foramen in one specimen (UU KR2 5018) situated on the right side in anterior view indicates that paracotylar foramina were probably present. Due to the damaged ventral portions of all vertebrae, it is not possible to determine whether the structure on the ventral surface of the centrum represents a haemal keel or a hypapophysis, although the presence of the former structure (haemal keel) might be more probable. As such, we refrain from assigning the Aliveri and Karydia colubrids to either 'colubrines' or 'natricines' (sensu Szyndlar 1984, 1991a, 1991b), although we must further acknowledge here that the presence or absence of a hypapophysis throughout the vertebral column is a widespread and variable feature and it should be dealt with high caution, when dealing with taxonomic designations and attributions (Pyron et al. 2013; Head et al. 2016). 
Whereas the caudal vertebra UU KR2 5025 and the two vertebral fragments (UU KR2 5020 and AMPG KR3 020) are not informative, the other three colubrid specimens (UU AL 3590, UU KR2 5018, and UU KR2 5019) are characterised by a combination of peculiar features and therefore, enable us to provisionally identify them as belonging to the same taxon. More particularly, the most striking features of this taxon are: (1) in lateral view, a highly distinct ridge, herein defined with the newly introduced term 'paracentral ridge', which is situated above the subcentral ridge and extends from the posterior margin of the diapophysis up to about half of the centrum length; (2) in ventral view, an almost triangular and rather highly elevated surface surrounding the posterior part of the haemal keel (or hypapophysis); (3) a prominent, deep and narrow haemal keel (or hypapophysis) with the ventral margin being sharp along its entire length; (4) prominent subcentral grooves; (5) rather sharp subcentral ridges which are strongly built; (6) rather large subcentral foramina with their orifices directed anteriorly; (7) large lateral foramina, situated in deep depressions; and (8) in dorsal view, a trilobate zygosphene, with distinct lateral lobes. The herein newly defined 'paracentral ridge' appears to be a unique feature and in fact has never been previously described in fossil or extant snakes (e.g. Szyndlar 1984, 1991a, 1991b; Holman 2000; Szyndlar 2005; LaDuke 1991). It is worth noting that in certain colubrids, the anterior portion of the subcentral ridge forms sometimes an elongate triangle whose tip is directed posteriorly, as if the ridge was forked anteriorly in two branches, a ventro-medial and a dorso-lateral one (J-C. Rage, pers. comm., December 2017). The paracentral ridge that is observed in our Greek fossil material, however, does not correspond to that case, as it clearly does not form a triangle and is not united with the subcentral ridge, and is also well projecting across most of the vertebra's lateral surface. Furthermore, we do not consider that this, apparently apomorphic, feature is the product of a pathology, since it is present symmetrically in both lateral views of the vertebrae and is present in both specimens from Karydia (not preserved in the Aliveri specimen). We were only able to identify a similar, but not identical, feature in the trunk vertebrae of the extant Asian snake Boiga sp. (specimen MDHC 137), although it is differently shaped and not as prominent as in the Greek fossils. Curiously, this feature on the vertebrae of Boiga was not mentioned at all by Ikeda (2007), and it cannot also be ascertained from the photographs provided in that publication. Of course, we are not implying a close relationship among Boiga and the Greek colubrid solely on the basis of this feature. Besides, their vertebrae are rather different in terms of general shape, size, and shape of vertebral structures. In any case, the presence of this unique feature, the paracentral ridge, and the combination of the other characters described above probably denote that the colubrid from Karydia and Aliveri is a new taxon. However, on the basis of the scarceness of the material and the rather incomplete and fragmentary nature of all specimens, we refrain from naming it as a new species.

Viperidae Oppel, 1811

Viperidae indet. (Figure 10)

Material. AL1a: an incomplete fang (UU AL 3592).

Description. The fang is incomplete and has its base unpreserved. The apical termination is slightly curved, with a wide pulpal cavity and venom canal situated anteriorly in central position (Figure 10). In dorsal view, the base of the entrance orifice, which
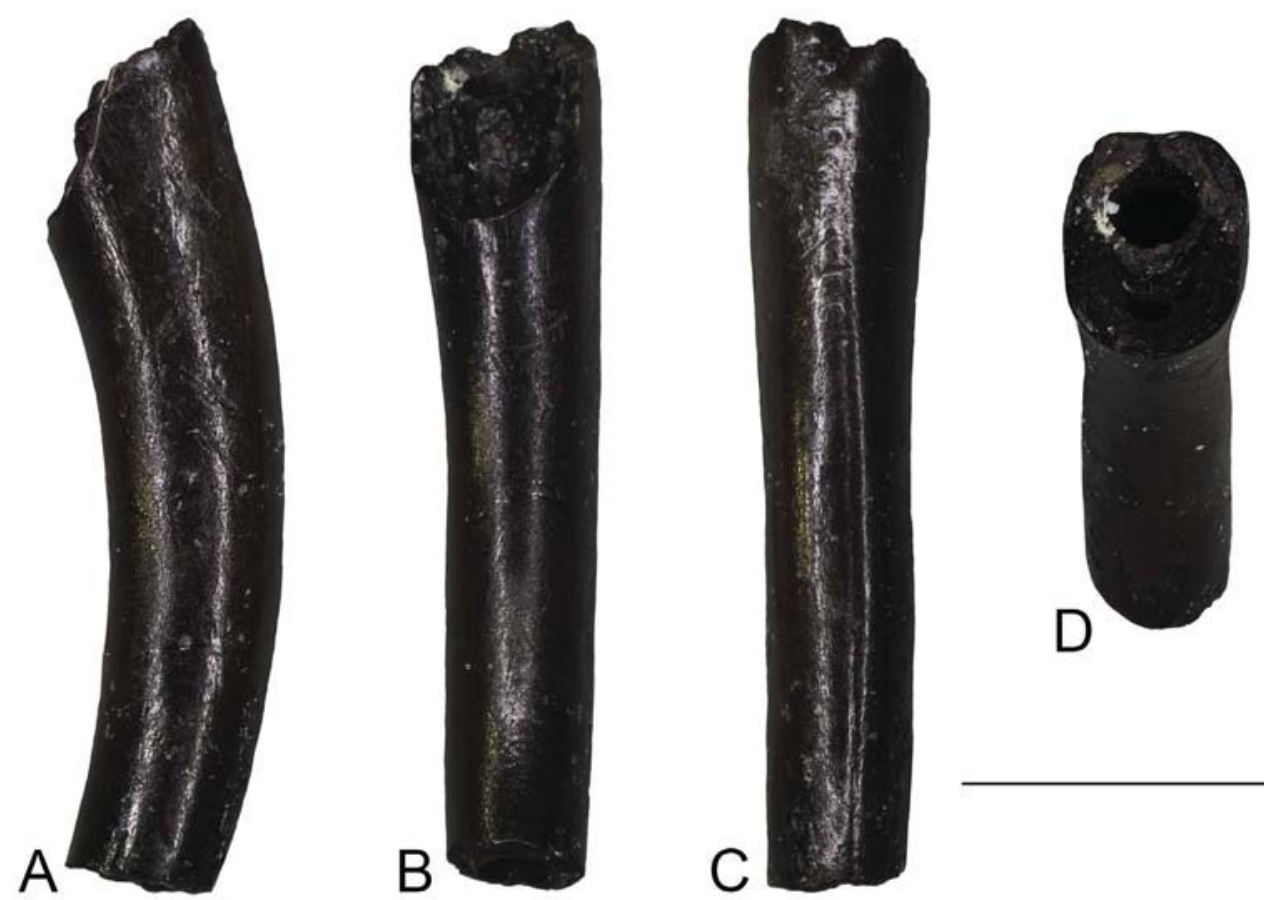

Figure 10. Viperidae indet. from Aliveri: isolated fang (UU AL 3592) in lateral (A), posterior (B), anterior (C), and dorsal (D) views.

Scale bars $=1 \mathrm{~mm}$. 
is situated in the anteriormost proximal part of the fragment, is indicated by the distinction of the dentine folds which form the anterior closure of the venom canal (Figure 10(D)). In anterior view, there is a distinct suture close to the distal termination of the fragment. This suture turns proximally into a narrow groove, which diminishes in front of the entrance orifice base where the fang surface is completely smooth. The discharge orifice is not preserved. A wide groove occurs on either lateral side of the fang along its entire length.

Remarks. The single, isolated fang from Aliveri can be assigned to viperids on the basis of the presence of a venom canal which originated from the dentine folding throughout ontogeny. This mode of venom canal development is typical for viperids (Jackson 2002; Zahradnicek et al. 2008). The fangs of elapid snakes differ by the presence of a distinct anterior groove connecting entrance and discharge orifices (Kuch et al. 2006). The distinct lateral grooves which stretch along the entire length of the fragment are rather unusual in viperids although short lateral grooves frequently occur in both crotalines and viperines at the vicinity of the fang base (see Figure 2 in Ivanov 1999; MI, pers. obs.). The preserved specimen from Aliveri is too fragmentary for a more precise determination at the subfamily level. However,

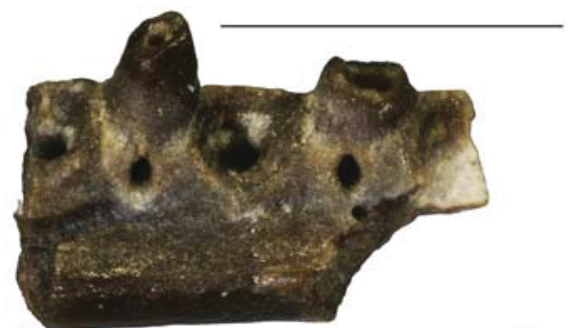

A
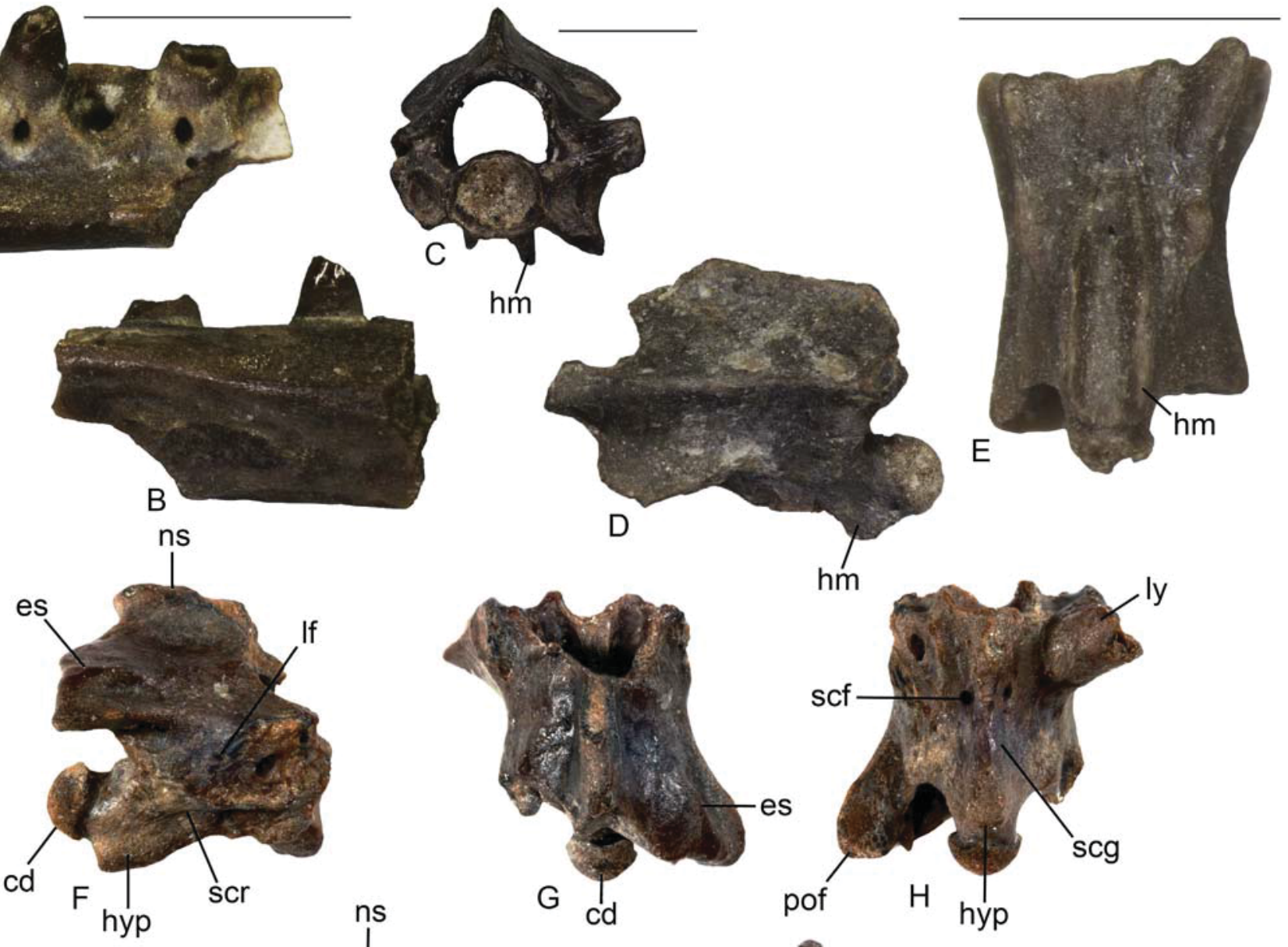

D
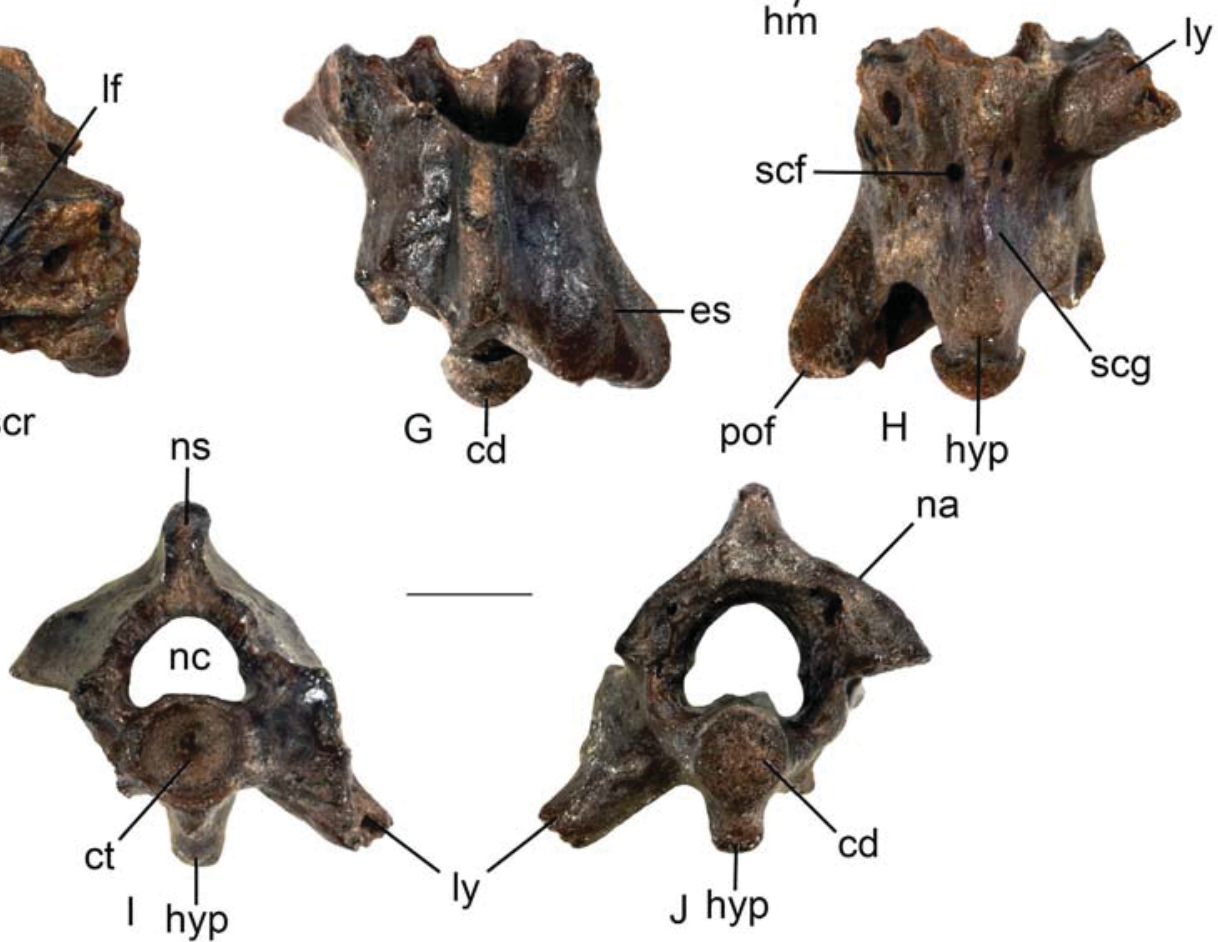

Figure 11. Serpentes indet. from Aliveri (A-B): fragment of the anterior part of a left pterygoid (UU AL 3529) in medial (A) and labial (B) views. Serpentes indet. from Karydia-3 (C-E): posterior caudal vertebra (AMPG KR3 021) in anterior (C) and left lateral (D) views; posterior caudal vertebra (AMPG KR3 022) in ventral (E) view. Serpentes indet from Karydia-2 (F-J): cloacal or anterior caudal vertebra (UU KR2 5022) in right lateral (F), dorsal (G), ventral (H), anterior (I), and posterior (J) views.

Scale bars = 1 mm. Abbreviations: cd, condyle; ct, cotyle; es, epizygapophyseal spine; hm, haemapophysis; hyp, hypapophysis; If, lateral foramen; ly, lymphapophysis; nc, neural canal; ns, neural spine; pof, postzygapophyseal facet; scf, subcentral foramen; scg, subcentral groove; scr, subcentral ridge. 
a possible taxonomic attribution to Viperinae could be indirectly supported by a biogeographic rationale, as Crotalinae are only known in Europe with certainty from the late Miocene (MN 9) of Ukraine (Ivanov 1999).

Serpentes indet. (Figure 11) Material. AL1a: a fragment of the anterior part of a left pterygoid (UU AL 3529). AL1980NQ: a vertebra (UU AL 3591). KR2: a cloacal or anterior caudal vertebra (UU KR2 5022), two fragmentary vertebrae (UU KR2 5023 and UU KR2 5024), and a cloacal or anterior caudal vertebra (UU KR2 5021). KR3: a fragment of a pterygoid (AMPG KR3 013), and two posterior caudal vertebrae (AMPG KR3 021 and AMPG KR3 022).

Remarks. These cranial and postcranial remains from Aliveri and Karydia are too fragmentary and incomplete to permit a more precise identification within snakes. It is worth noting, however, that one of these specimens, UU KR2 5022, seems to demonstrate a mixed character set between colubroids and booids (Figure $11(\mathrm{~F})-(\mathrm{J}))$. This vertebra most probably originates from the cloacal region, as it can be judged by the presence of a strongly built, short hypapophysis and the preserved base of the ventral ramus of the left lymphapophysis, although an alternative origin from the anterior caudal region cannot be excluded. The relatively massive structure of the vertebra UU KR2 5022, with a strongly built neural spine and short hypapophysis, as well as the absence of paracotylar foramina, is reminiscent of certain Booidea (e.g. Rage 1984; Szyndlar and Rage 2003), but the ratio of a centrum length/neural arch width $>1$ and a condyle situated on a rather long neck are not typical for cloacal vertebrae of Booidea and are mostly characterising colubroids (e.g. Rage 1984). To make things even more complicated, several non-pythonid booids, both extinct (e.g. Bavarioboa) and extant (e.g. Boa), are also known to possess paracotylar foramina, in at least some of their vertebrae (Szyndlar and Rage 2003), rendering obscure the taxonomic reliability of this character. As such, we herein refrain from identifying UU KR2 5022 as a booid and prefer to refer it as Serpentes indet.

Squamata indet.
Material. AL1a: four fragments of tooth-bearing bones (UU AL 3522, UU AL 3523, UU AL 3525, and UU AL 3526), a caudal vertebra (UU AL 3527), and fragments of a vertebra and a maxilla (UU AL 3528). AL1b: a pterygoid (UU AL 3588) and a humerus (UU AL 3589). KR3: a caudal vertebra (AMPG KR3 025) and an osteoderm (AMPG KR3 009).

Remarks. The above mentioned specimens from Aliveri are either too poorly preserved or they lack significant diagnostic features for a more precise taxonomic attribution. As such, they are attributed only to indeterminate squamates. Similarly, the two specimens from Karydia-3 represent skeletal elements of lizards that are considered not to bear significant diagnostic features. Nevertheless, the caudal vertebra is rather small-sized (centrum length is less than $2 \mathrm{~mm}$ ) and could therefore belong to the previously mentioned small-sized lacertid. The osteoderm, on the other hand, is different from anguid ones in shape, general morphology and ornamentation, being more similar to supraocular osteoderms of, e.g. lacertids. Given that, it could also belong to that clade.

\section{Discussion}

\section{Biogeographic implications of the Aliveri and Karydia herpetofaunas}

Both Aliveri and Karydia share common herpetofaunal elements, such as alytids, lacertids, and colubrids (Table 1). Notably, however, crocodylians, chamaeleonids, and viperids are known from Aliveri but are absent from Karydia, whereas the opposite case is known for salamanders. Of course, with the limited material currently available, it is not possible to state whether such faunistic differences among the two localities are indeed genuine and could imply ecological differences, or they are simply biased by taphonomical or incomplete collection factors. Definitely, however, the fact that Karydia has yielded significantly lower amount of fossil specimens in comparison with Aliveri might partially explain such faunistic differences among the two localities.

Table 1. Known occurrences of amphibians and reptiles in the early Miocene of Greece.

\begin{tabular}{|c|c|c|c|c|c|}
\hline & Aliveri (MN 4a) & Karydia (MN 4a) & Kymi (MN 3/4) & $\begin{array}{c}\text { Nostimo } \\
\text { (Burdigalian) }\end{array}$ & Lapsarna (?MN 3) \\
\hline ?Mioproteus sp. & & & & & + \\
\hline Urodela indet. & & + & & & \\
\hline Latonia cf. gigantea & & + & & & \\
\hline cf. Latonia sp. & + & & & & \\
\hline Anura indet. & + & + & & & + \\
\hline Nostimochelone lampra & & & & + & \\
\hline Testudines indet. & + & + & & & \\
\hline Crocodylia indet. & + & + & & & + \\
\hline Chamaeleo cf. andrusovi and Chamaeleonidae indet. & + & & & & \\
\hline Lacertidae indet. & + & + & & & + \\
\hline Scincomorpha indet. & + & + & & & \\
\hline cf. Ophisaurus sp. & & + & & & \\
\hline Anguinae indet. & + & + & & & \\
\hline Python euboicus & & & + & & \\
\hline ?Natricinae indet. & & & & & + \\
\hline Colubridae indet. & + & + & & & \\
\hline Viperidae indet. & + & & & & \\
\hline Serpentes indet. & + & + & & & + \\
\hline Squamata indet. (non-snake squamates) & + & + & & & + \\
\hline
\end{tabular}

Data from: Aliveri-Georgalis, Villa, and Delfino (2016b) and this paper; Karydia-this paper; Kymi-Römer (1870); Nostimo-Georgalis et al. (2013); Lapsarna Vasileiadou et al. 2017. 
The single known salamander element from Karydia is not informative for a precise taxonomic identification, but still represents, along with a recently described probable proteid from Lapsarna (Lesvos) (Vasileiadou et al. 2017), the oldest urodelan remains from Greece, both being also the sole Neogene occurrences from the country. The frog remains from Karydia (and potentially also Aliveri) document the presence of Latonia for the first time in Greece and are fully concordant with the widespread European range of that genus during the early Neogene (Roček 1994; see also below). The fragmentary nature of the Aliveri and Karydia turtle specimens does not permit any further biogeographic assumption, but nevertheless, these constitute the oldest such remains from Greece, along with the holotype of Nostimochelone lampra from the Burdigalian of Nostimo (administrative region of Western Macedonia) (Georgalis et al. 2013). Crocodylians are rather rare in the Greek fossil record, and as such, they had only recently been described for the first time from the late Miocene of Plakias (Crete) (Georgalis, Villa, Vlachos et al. 2016) and soon after from the early Miocene of Lapsarna (Lesvos) (Vasileiadou et al. 2017). In any case, the new Aliveri remains demonstrate that crocodylians were more widespread in the early Miocene of the region, a situation consistent with similar finds from the Oligo-Miocene of Turkey (Schleich 1994; Sen et al. 2011). As for the lizards, the presence of a chamaeleonid in Aliveri was recently shown to support a probable Greek pathway for this African clade that could have used the 'Gomphotherium Landbridge' for its dispersal (Georgalis, Villa and Delfino 2016). Newly described chamaeleonid remains from the early Miocene (MN 4) of Sibnica, Serbia (Đurić 2016) suggest that chameleons were more widespread faunal elements in the southern Balkan localities of that time, than what was previously thought. This clade is still absent from the as of yet poor fossil record of squamates from Anatolia. The herein described lacertids from Aliveri and Karydia, along with the recently described Lapsarna material (Vasileiadou et al. 2017), demonstrate that these lizards were already widespread in Greece already by the early Miocene and would since then continue to be a common element of the Greek herpetofaunas. Indeed, lacertids were also described from late Miocene localities of the region (Richter 1995; Georgalis et al. 2017a) and they are currently the dominant (in terms of diversity) reptile group on the European continent (Arnold et al. 2007; Sindaco and Jeremčenko 2008). The Aliveri and Karydia anguids are the oldest representatives of this clade from Greece, though they have been described from the early Miocene of Sibnica, Serbia (Đurić 2016) and various coeval localities from Turkey (Čerňanský et al. 2017), confirming their wide distribution in the area already by the early Neogene. The apparently bizarre colubrid snake from Karydia and its potentially conspecific form from Aliveri seem to possess unique autapomophies that are otherwise unknown in extinct and extant European snakes, most significantly the presence of a new vertebral feature that is herein termed as 'paracentral ridge.' The skeletal anatomy of extant African and Asian snakes is poorly documented so it is currently impossible to identify the presence of a paracentral ridge in modern taxa and to assess its potential diagnostic importance. Considering, however, that this feature is totally absent in all European extinct and extant snakes, it seems plausible that the herein newly described early Miocene Greek colubrids could represent a shortly lived radiation with African or Asian origin.
The isolated snake fang from Aliveri denotes the presence of viperid snakes in Greece already by the early Miocene, being the oldest representative from that clade in the region, a presence that culminated with the magnificent Laophis crotaloides Owen 1857 , one of the largest known viperids, from the Pliocene of Thessaloniki area (Georgalis, Szyndlar, et al. 2016).

\section{Frogs of the genus Latonia in the early Neogene of southeastern Europe}

Latonia is a genus of discoglossine alytid frogs that thrived in Europe from the late Oligocene up to the early Pleistocene (Roček 1994, 2013; Delfino 2002), becoming the most common alytid in the continent during the Miocene. The genus may have also been present during the early Oligocene, considering a mention of Latonia aff. vertaizoni from Quercy (Rage 2006), however, this material is undescribed and still awaits a formal documentation. Starting from the Pliocene, the European range of Latonia underwent a southward directed contraction, which eventually resulted in its local extirpation during the Pleistocene. It has been suggested that this extinction event has been linked to Pleistocene climate change (Roček 1994). Nevertheless, Latonia has been documented in the early Pleistocene of Anatolia (Vasilyan et al. 2014) and it is also now known that the genus has survived in the Middle East, where the only extant representative, Latonia nigriventer (Mendelssohn and Steinitz 1943) still exists, being its sole living representative (Biton et al. 2013, 2016). Although several taxa have been assigned to this genus, it is now generally accepted that only four valid extinct species are known from Europe (Roček 1994): Latonia seyfriedi Meyer, 1843 (type species), Latonia gigantea (Lartet, 1851), Latonia ragei Hossini, 1993, and Latonia vertaizoni (Friant, 1944).

The remains of Latonia from Karydia-3 share a similar morphology and size with juveniles of Latonia gigantea, notwithstanding the possible presence of the foramen for the occipital artery. Assuming that our attribution of these fossils to Latonia cf. gigantea is correct, Karydia- 3 would be one of the southernmost localities from which this species (or at least a morphologically rather similar form) is reported. As a matter of fact, the new Greek occurrence adds to the tentatively attributed remains from the Gargano palaeoisland in Southern Italy (Delfino 2002) and to the recently described remains from Catalonia in the Iberian Peninsula (Villa et al. 2017). This supports the hypothesis that the seemingly poor representation of L. gigantea in the Mediterranean area, compared with the fossil record of that species in the rest of Europe (Roček 1994, 2013), might be an artifact of either misidentification or overlooking of fossil remains, rather than a real absence from the area. Further studies on Latonia remains that are currently unassigned to the species level and originate from other localities in the southern European peninsulas might shed more light on this issue. Indeed, recently described remains (an ilium and an urostyle) from the early Miocene of Sibnica, Serbia, have been attributed to Latonia cf. gigantea (Đurić 2016), though they were not figured and, as such, we cannot confirm their identity. It has to be noted, however, that neither ilia nor urostyles are usually considered diagnostic for Latonia species, and therefore the identification of the Serbian material must be treated with caution. Moreover, remains from Karydia-3 could also represent the oldest occurrence of the species, given that this 
locality is considered as probably slightly older than both Dolnice (Czech Republic) and Günzburg (Germany), from which the oldest published remains of Latonia gigantea are currently known (Roček 1994, 2013; Böhme 2003).

In any case, the herein-described Latonia fossils represent the first published occurrences of the genus in Greece. Its tentative identification from Aliveri, located relatively far from Karydia (more than $300 \mathrm{~km}$ straightline distance), suggests a rather widespread distribution of these anurans in the southern part of the Balkan Peninsula during the early Miocene, a view that is also corroborated by their possible presence in the coeval Serbian locality of Sibnica. Nevertheless, whether the Aliveri remains pertain indeed to Latonia, needs to be confirmed by more diagnostic material from this or at least from other coeval sites nearby.

\section{Early Miocene herpetofaunas from southeastern Europe}

The early Miocene is a rather important time interval for the herpetofaunas of Europe, as it witnesses the transition between the Oligocene to the Miocene and, therefore, records the turning point between a relatively cool and dry Oligocene stage towards a much warmer and humid climate in the early Miocene (Rage and Roček 2003; Rage 2013; Čerňanský et al. 2015). Moreover, this epoch coincides with a wave of new immigrant vertebrate taxa that penetrated to Europe, affecting dramatically the autochthonous faunas of the continent (Ivanov 2001; Rage and Roček 2003; Čerňanský 2012). Several Asian terrestrial taxa are known to have dispersed to Europe during the early Miocene, among which also reptiles (Ivanov 2001; Szyndlar 2012). Moreover, a large number of these dispersals seems to have been facilitated by the collision of the Afro-Arabian plate which created the so called 'Gomphotherium Landbridge' and allowed a wave of African terrestrial immigrants to enter Eurasia. This event took place at around the MN 3 zone of the early Miocene and, as the name readily suggests, resulted in the establishment of a land contact between northeastern Afro-Arabia and Eurasia, diminishing thus, the marine barrier that was previously separating them (Rögl 1999; Koufos et al. 2005; Georgalis, Villa and Delfino 2016). This new land corridor acted as a platform that enabled dispersals between Eurasia and Afro-Arabia. This dispersal event caused radical faunal turnovers, ecological changes, substitutions, and extinctions across Europe. Several tetrapod terrestrial taxa are known to have dispersed from the AfroArabian continent to Europe, through Anatolia and the Balkan Peninsula, among which numerous mammal clades (e.g. Koufos et al. 2003, 2005), but also reptiles, such as chamaeleonids and cordylids (Čerňanský 2012; Georgalis, Villa and Delfino 2016). The opposite kind of dispersal, with a direction from Europe to Africa, has been suggested also for other reptiles, such as the anguine Ophisaurus (Blain et al. 2013; Čerňanský et al. 2017). Moreover, the Miocene Climatic Optimum, the beginning of which coincides at around that time period, favored the northward expansion of several thermophilic taxa, such as chamaeleonids, cordylids, and several crocodylians and turtles, that all reached their northernmost distribution by that time (Roček 1984; Böhme 2003; Čerňanský 2010). As a consequence, new clades of amphibians and reptiles appeared in the early Miocene Europe for the first time, or reappeared after millions of years after their last occurrence, whereas other clades were inevitably driven to their final demise and extinction. Two amphibian clades, bufonids and pelodytids, that had been recorded from Europe in the Paleocene and Eocene respectively, but not known then after, reappeared again in the continent, with new representatives at the early Miocene (Rage 2003, 2012; Rage and Roček 2003). Notably also, hylid frogs appeared in Europe during the early Miocene (MN 4) for the first time (Rage and Roček 2003). Moreover, various extant reptile genera, such as the turtle Rafetus, the lizards Pseudopus and Varanus, and the snakes Naja and Python, made their first European appearance during the early Miocene (Szyndlar and Rage 2003; Klembara 2012; Delfino et al. 2013; Rage 2013; Georgalis and Joyce 2017; Georgalis et al. 2017b; Ivanov et al. 2017), although their exact origins are not yet fully resolved. The case of Varanus is rather interesting, as it marks the reappearance of varanids in Europe, considering that this clade was represented in the Paleogene of the continent by a different genus (Saniwa) but had become extinct during the late Eocene (Rage 2013; Georgalis et al., 2017b). Shinisaur lizards became totally extinct in Europe at the early Miocene, with their last, sporadic occurrences recorded from the Czech Republic and Germany (Klembara 2008; Čerňanský et al. 2015). Viperids and elapids became brand new representatives for the European snake fauna, as they appeared for the first time in the continent at the earliest Miocene (Kuch et al. 2006; Rage 2013; Čerňanský et al. 2015; Georgalis, Szyndlar, et al. 2016). In parallel, colubrids began to thrive since then, towards an unbalanced competition with booids, the snake group that was dominant during the Paleogene (Szyndlar 2012). The diversity drop within Booidea was rather severe, being labeled in the literature as the 'Dark Period of booid snakes', and spanning from the latest Oligocene to the earliest Miocene (Szyndlar and Rage 2003; Rage and Szyndlar 2005). Finally, the enigmatic Choristodera, an ancient reptile lineage that originated in the Triassic, made its last global appearance in the fossil record during the early Miocene (MN 3) of the Czech Republic (Evans and Klembara 2005).

However, there is still a large gap in our knowledge of early Miocene herpetofaunas of Europe, which is mostly caused by the relative scarcity of localities of this age (especially Aquitanian) in the continent (Čerňanský et al. 2015, 2016). Few earliest Miocene (Aquitanian) localities have produced amphibian and/or reptile remains, the majority of which are turtles. Amphibians, crocodylians, and squamates have far more seldom occurrences, mostly consisting of fragmentary remains. The situation appears to be relatively better for the Burdigalian record, where several localities are known from Central and Western Europe, with far more amphibian and reptile finds and thus providing a better comprehension of their herpetofauna. This scarcity of localities severely hinders our understanding of important events that took place at that time interval. Furthermore, the exact biogeographic routes of the dispersals events that took place at that time are not yet well defined, as this fact is dramatically hampered by a huge gap in our knowledge of southeastern Europe's early Miocene faunas.

Greek localities from this age interval are rather rare and incompletely studied (Koufos 2006). Moreover, in most of these cases, fossil herpetofauna is not the main target of field work or study, being frequently neglected in favor of mammal finds (Georgalis, Villa, Vlachos et al. 2016). As such, up to that date only few records of early Miocene amphibians and reptiles have been described 
from Greece (Römer 1870; Georgalis et al. 2013; Georgalis, Villa and Delfino 2016; Vasileiadou et al. 2017) (Table 1). The situation is rather similar in adjacent regions, with only few early Miocene amphibians and reptiles described up to date from southern Balkans (Đurić 2016) and Anatolia (Čerňanský et al. 2017). This is rather frustrating, considering that various biogeographic scenaria, dispersal routes, and potential ecological refugia, altogether highlight the important role of the Greek area at around the early Miocene. Several Asian and African amphibian and reptile groups are inferred to have used Greece as the corridor towards their European expansion, whereas certain northern taxa are believed to have moved southwards during climatic deterioration.

So far, the majority of early Miocene herpetofaunal elements from Greece consists mostly of rather fragmentary remains with no apparent taxonomic usefulness, but important specimens have, nevertheless, been recovered. No amphibian and just two reptile taxa from Greece have been named from this time interval: Python euboicus Römer 1870; and Nostimochelone lampra Georgalis et al., 2012 (for 2013), both known only from their holotypes in their type localities. Additionally, only two other forms have been referred to the species level Chamaeleo cf. andrusovi from Aliveri (Georgalis, Villa and Delfino 2016) and the herein described Karydia material attributed to Latonia cf. gigantea. Python euboicus is a large sized pythonid snake from the early Miocene of Kymi, Euboea (Römer 1870). The age of Kymi was initially thought to be from the MN 3 zone, but recently it has been suggested that it is from the MN 4 (Szyndlar and Rage 2003). The unfortunate fact that the rather complete holotype skeleton (and only known specimen) is lost hinders the exact taxonomic status and phylogenetic affinities of this taxon. Nostimochelone lampra is a podocnemidoidean pleurodire turtle from the early Miocene (Burdigalian) of Nostimo, northwestern Greece (Georgalis et al. 2013). Apart from being the first and only known pleurodire from the region, Nostimochelone lampra represents also one of the youngest representatives of this group for the whole European continent (Georgalis and Kear 2013; Georgalis et al. 2013). The recently described chamaeleonid material from Aliveri (Chamaeleo cf. andrusovi) was shown to bear strong resemblance with roughly coeval forms from the Czech Republic, highlighting a possible dispersal pathway of these lizards from Africa to Anatolia and from there to Greece and then to Central Europe (Georgalis, Villa and Delfino 2016). Therefore, fossil amphibians and reptiles from the localities of Kymi, Nostimo, Lapsarna, Aliveri, and Karydia fill thus an important gap into the early Miocene Greek herpetofaunal vacuum and, as such, are crucial for the understanding of the evolution, taxonomy, and biogeography of these groups in Europe.

\section{Conclusions}

We herein describe fossil amphibians and reptiles from two early Miocene (MN 4) Greek localities, Aliveri and Karydia. Together, these two herpetofaunas have yielded a relatively diverse assemblage consisting of urodelans, alytids, indeterminate anurans, turtles, crocodylians, chamaeleonids, lacertids, indeterminate scincomorphs, anguids, colubrids, viperids, and indeterminate snakes. The frog Latonia cf. gigantea is described from Greece for the first time and provides implications about the distribution and evolution of that amphibian lineage in Europe. The presence of a viperid in Aliveri denotes that this snake clade achieved a much wider distribution already during the early Neogene of Europe, than what was previously thought. We additionally identify a colubrid that is characterised by a unique combination of features and above all, the presence of an as yet unknown vertebral structure in the lateral walls of the centrum, for which we here introduce the term 'paracentral ridge'. The palaeobiogeography of the European herpetofauna during the early Miocene is discussed. Multiple dispersal events from both Asia and Africa, in combination with major climatic changes (beginning of the Miocene Thermal Maximum) resulted in appearances of new immigrant taxa, extinction events, and significant faunal turnovers that all drastically altered European herpetofaunas. The geographic position of Greece at the edge of southeastern Europe played an important role in dispersals that were facilitated through the collision of the Afro-Arabian plate with Eurasia and the emergence of the 'Gomphotherium Landbridge' during the early Miocene. The newly described specimens from Aliveri and Karydia partially fill a gap into our knowledge of the early Miocene amphibians and reptiles from this region.

\section{Acknowledgements}

We would like to acknowledge Wilma Wessels and Hans de Bruijn (University of Utrecht) for the loan of several specimens described in this paper and also Constantin Doukas (National and Kapodistrian University of Athens) for providing us information regarding the Aliveri and Karydia localities. We thank Rebecca Biton (University of Torino) for useful discussions about identification and distribution of Latonia. We also thank Walter Joyce (University of Fribourg) and Zbigniew Szyndlar (ZZSiD) for useful comments that enhanced the quality of the manuscript. Our special thanks also to our Editor Gareth Dyke (University of Southampton) and our reviewers Andrej Čerňanský (Comenius University of Bratislava) and Jean-Claude Rage (MNHN) for their insightful comments that improved the quality of the manuscript.

\section{Disclosure statement}

No potential conflict of interest was reported by the authors.

\section{Funding}

This work was supported by the study of comparative skeletal material of extant amphibians and reptiles funded by SYNTHESYS ES-TAF-5910 (MNCN), SYNTHESYS AT-TAF-5911 (NHMW), and SYNTHESYS HU-TAF-6145 (HNHM) grants to GLG, and SYNTHESYS FR-TAF-5007 (MNHN) and SYNTHESYS AT-TAF-4591 (NHMW) to AV, and the curators of these institutions, respectively Marta Calvo-Revuelta, Heinz Grillitsch, Judit Vörös, and Salvador Bailon are highly thanked here. MD acknowledges economical support from Fondi di Ateneo Università di Torino (2016-2017) and Generalitat de Catalunya/CERCA Programme, Agencia Estatal de Investigación (AEI) from Spain/European Regional Development Fund of the European Union (CGL2016-76431-P].

\section{ORCID}

Massimo Delfino (iD http://orcid.org/0000-0001-7836-7265

\section{References}

Arnold EN, Arribas O, Carranza S. 2007. Systematics of the palaearctic and oriental lizard tribe C. Lacertini (Squamata: Lacertidae: Lacertinae), with descriptions of eight new genera. Zootaxa. 1430:1-86. 
Augé ML. 2005. Evolution des lézards du Paléogène en Europe [Evolution of lizards from the Paleogene of Europe]. Mém Mus Natl d'Hist Nat. 192:3-369.

Bailon S. 1991. Amphibiens et Reptiles du Pliocène et du Quaternaire de France et d'Espagne: mise en place et évolution des faunes [Amphibians and reptiles from the Pliocene and Quaternary of France and Spain] [PhD dissertation]. Paris: Université de Paris VII.

Bailon S. 1999. Différenciation ostéologique des anoures (Amphibia, Anura) de France [Osteological differentiation of anurans (Amphibia, Anura) from France]. In: Desse J, Desse-Berset N, editors. Fiches d’ostéologie animale pour l'Archéologie [Animal Osteology Sheets for Archeology], Série C: Varia, 1. Antibes: APDCA; p. 1-41.

Barahona FF. 1996. Osteología craneal de lacértidos de la Península Ibérica e Islas Canarias: análisis sistemático filogenético [Cranial osteology of lacertids from the Iberian Peninsula: systematic and phylogenetic analysis]. [PhD dissertation]. Madrid: Universidad Autónoma de Madrid.

Batsch AJGC. 1788. Versuch einer Anleitung, zur Kenntniß und Geschichte der Thiere und Mineralien, für akademische Vorlesungen entworfen, und mit den nöthigsten Abbildungen versehen, Erster Theil Allgemeine Geschichte der Natur; besondre der Saügthiere, Vögel, Amphibien und Fische. Jena: Akademische Buchhandlung.

Biton R, Geffen E, Vences M, Cohen O, Bailon S, Rabinovich R, Malka Y, Oron T, Boistel R, Brumfeld V, Gafny S. 2013. The rediscovered Hula painted frog is a living fossil. Nat Commun. 4:1959.

Biton R, Boistel R, Rabinovich R, Gafny S, Brumfeld V, Bailon S. 2016. Osteological observations on the alytid anuran Latonia nigriventer with comments on functional morphology, biogeography, and evolutionary history. J Morphol. 277:1131-1145.

Blain H-A, Agustí J, López-García JM, Haddoumi H, Aouraghe H, Hammouti K, Pérez-González A, Chacón MG, Sala R. 2013. Amphibians and squamate reptiles from the late Miocene (Vallesian) of eastern Morocco (Guefait-1, Jerada Province). J Vertebr Paleontol. 33:804-816.

de Blainville HM. 1816. Prodrome d'une nouvelle distribution systématique du règne animal. Bull Sci Soc Philom Paris. 8:113-124.

Böhme M. 2003. The Miocene Climatic Optimum: evidence from ectothermic vertebrates of Central Europe. Palaeogeogr Palaeoclimato Palaeoecol. 195:389-401.

de Bruijn H. 2017. A new stage in the evolution of the mole rats (Rodentia Spalacinae) from the Early Miocene of northern Greece. Hist Biol 29:571-575.

de Bruijn H, van der Meulen AJ. 1979. A review of the Neogene rodent succesion in Greece. Ann Geol des Pays Helleniques. 1979:207-217.

de Bruijn H, van der Meulen AJ, Katsikatsos G. 1980. The mammals from the lower Miocene of Aliveri (Island of Evia, Greece) 1. The Sciuridae. Proc Koninkl Nederl Akad Wetensc Ser B. 83:241-261.

Camp CL. 1923. Classification of the lizards. Bul Am Mus Nat Hist. 48:289-481.

Čerňanský A. 2010. A revision of chamaeleonids from the Lower Miocene of the Czech Republic with description of a new species of Chamaeleo (Squamata, Chamaeleonidae). Geobios. 43:605-613.

Čerňanský A. 2012. The oldest known European Neogene girdled lizard fauna (Squamata, Cordylidae), with comments on Early Miocene immigration of African taxa. Geodiversitas. 34:837-848.

Čerňanský A, Tóth C, Šurka J. 2012. Crocodylian and turtle finds from the Lower Miocene of the Baňa Dolina mine in Velký Krtíš (Slovakia). Acta Geol Slovaca. 4:113-123. [in Slovak with English summary].

Cerňanský A, Rage J-C, Klembara J. 2015. The early miocene squamates of Amöneburg (Germany): the first stages of modern squamates in Europe. J Syst Palaeontol. 13:97-128.

Čerňanský A, Klembara J, Smith KT. 2016. Fossil lizard from central Europe resolves the origin of large body size and herbivory in giant Canary Island lacertids. Zool J Linn Soc. 176:861-877.

Čerňanský A, Vasilyan D, Georgalis GL, Joniak P, Mayda S, Klembara J. 2017. First record of fossil anguines (Squamata; Anguidae) from the Oligocene and Miocene of Turkey. Swiss J Geosci. 110:741-751.

Cope ED. 1864. On the characters of the higher groups of Reptilia Squamata - and especially of the Diploglossa. Proc Acad Nat Sci Philad. 1864:224-231.

Daudin FM. 1803. Histoire naturelle, générale et particulière des reptiles: ouvrage faisant suite à l'Histoire naturelle générale et particulière, composée par Leclerc de Buffon, et rédigée par CS Sonnini Tome septième. Paris: F. Dufart; 436 pp.

Delfino M. 2002. Erpetofaune italiane del Neogene e del Quaternario Italian herpetofaunas from the Neogene and the Quaternary] [PhD dissertation]. Modena (Italy): University of Modena and Reggio Emilia.

Delfino M, Rage J-C, Rook L. 2003. Tertiary mammal turnover phenomena: what happened to the herpetofauna? In: Reumer JWF, Wessels W, editors. Distribution and migration of Tertiary mammals in Eurasia, a volume in honour of Hans de Bruijn. Deinsea. 10, p. 153-161.

Delfino M, Böhme M, Rook L. 2007. First European evidence for transcontinental dispersal of Crocodylus (late Neogene of southern Italy). Zool J Linn Soc. 149:293-307.

Delfino M, Bailon S, Pitruzzella G. 2011. The Late Pliocene amphibians and reptiles from "Capo Mannu D1 Local Fauna" (Mandriola, Sardinia, Italy). Geodiversitas. 33:357-382.

Delfino M, Rage J-C, Bolet A, Alba DM. 2013. Early Miocene dispersal of the lizard Varanus into Europe: reassessment of vertebral material from Spain. Acta Palaeontol Pol. 58:731-735.

Doukas CS. 2003. The MN4 faunas of Aliveri and Karydia (Greece) Coloquios de Paleontología, Volumen Extraordinario. 1:127-132.

Doukas CS. 2005. Greece. In: van den Hoek Ostende LW, Doukas CS, Reumer JWF, editors. The fossil record of the Eurasian Neogene Insectivores (Erinaceomorpha, Soricomorpha, Mammalia), Part I Scripta Geologica Special Issue. 5, p. 99-112.

Doukas CS, van den Hoek Ostende LW. 2006. Insectivores(Erinaceomorpha, Soricomorpha; Mammalia) from Karydia and Komotini (Thrace, Greece; MN 4/5). Beiträge zur Paläontologie. 30:109-131.

Duméril AMC. 1806. Zoologie analytique, ou méthode naturelle de classification des animaux, rendue plus facile à l'aide de tableaux synoptiques. Paris: Allais; p. 544

Đurić D. 2016. The Early Miocene herpetofauna (Amphibia and Squamata) from Sibnica, Serbia. In: Marković Z, Milivojević M, editors. The Neogene of Sibnica and vicinity (Levač basin, Central Serbia) Part 1. Belgrade. Natural History Museum in Belgrade Special issue; p. 57-61.

Estes R. 1983. Sauria Terrestria, Amphisbaenia. In: Wellnhofer P, editor Encyclopedia of paleoherpetology. Stuttgart: Gustav Fisher Verlag; 249 $\mathrm{pp}$

Estes R, de Queiroz K, Gauthier J. 1988. Phylogenetic relationships within Squamata. In: Estes R, Pregill G, editors. Phylogenetic relationships of the lizard families. Stanford, CA: Stanford University Press; p. 119-282.

Evans SE. 2008. The skull of lizards and tuatara. In: Gans C, Gaunt AS, Adler $\mathrm{K}$, editors. Biology of the reptilia volume 20 the skull of Lepidosauria. Ithaca (NY): Society for the Study of Amphibians and Reptiles; p. 1-347.

Evans SE, Klembara J. 2005. A choristoderan reptile (Reptilia: Diapsida) from the Lower Miocene of Northwest Bohemia (Czech Republic). J Vertebr Paleontol. 25:171-184.

Fischer von Waldheim G. 1813. Zoognosia tabulis synopticis illustrata usum praelectionum academiae imperialis medico-chirurgicae mosquensis edita. Vol. 1. Moscow: Nicolai Sergeidis Vsevolozsky.

Fitzinger LJFJ. 1843. Systema Reptilium. Fasciculus Primus. Vienna: Braumüller et Seidel.

Frey E, Monninger S. 2010. Lost in action-the isolated crocodilian teeth from Enspel and their interpretive value. Palaeobiodivers Palaeoenviron. 90:65-81.

Friant M. 1944. Caractères anatomiques d'un batracien oligocène de la Limagne, le Prodiscoglossus vertaizoni nov. gen. nov. spec [Anatomical characters of an Oligocene batrachian from Limagne, Prodiscoglossus vertaizoni nov. gen. nov. sp]. C R Hebd Seances Acad Sci. 219:561-562.

FürbringerM.1900.Zurvergleichenden anatomie des Brustschulterapparates und der Schultermuskeln. Jenaische Z. 34:215-718.

Georgalis GL, Joyce WG. 2017. A review of the fossil record of old world turtles of the clade Pan-Trionychidae. Bull Peab Mus Nat Hist. 58:115208.

Georgalis GL, Kear BP. 2013. The fossil turtles of Greece: an overview of taxonomy and distribution. Geobios. 46:299-311.

Georgalis GL, Velitzelos E, Velitzelos D, Kear BP. 2013. Nostimochelone lampra gen. et sp. nov., an enigmatic new podocnemidoidean turtle from the lower Miocene of northern Greece. In: Brinkman D, Holroyd P, Gardner J, editors. Morphology and evolution of turtles: papers in honor of Eugene S Gaffney Volume 3 Pleurodires. Dordrecht (The Netherlands): Springer; p. 277-287. 
Georgalis GL, Szyndlar Z, Kear BP, Delfino M. 2016. New material of Laophis crotaloides, an enigmatic giant snake from Greece, with an overview of the largest fossil European vipers. Swiss J Geosci. 109:103116.

Georgalis GL, Villa A, Delfino M. 2016. First description of a fossil chamaeleonid from Greece and its relevance for the European biogeographic history of the group. Sci Nat. 103:47.

Georgalis GL, Villa A, Vlachos E, Delfino M. 2016. Fossil amphibians and reptiles from Plakias, Crete: a glimpse into the earliest late Miocene herpetofaunas of southeastern Europe. Geobios. 49:433-444.

Georgalis GL, Villa A, Delfino M. 2017a. Fossil lizards and snakes from Ano Metochi - a diverse squamate fauna from the latest Miocene of northern Greece. Hist Biol. 29:730-742.

Georgalis GL, Villa A, Delfino M. 2017b. The last European varanid: demise and extinction of monitor lizards (Squamata, Varanidae) from Europe. J Vertebr Paleontol. 37:e1301946.

Gmelin JF. 1789. Tom. I. Pars III. In: Beer GE, editors, Caroli a Linné, Systema Naturae. Leipzig: Impensis Georg. Emanuel. Beer. p. 10331516.

Gray JE. 1825. A synopsis of the genera of Reptiles and Amphibia, with a description of some new species. Ann Philos Ser. 2(10):193-217.

Head JJ, Mahlow K, Müller J. 2016. Fossil calibration dates for molecular phylogenetic analysis of snakes 2: Caenophidia, Colubroidea, Elapoidea, Colubridae. Palaeontol Electronica. 19.2.2FC:1-21.

van den Hoek Ostende LW, Mayda S, Oliver A, Madern A, HernándezBallarín V, Peláez-Campomanes P. 2015. Aliveri revisited, a biogeographical appraisal of the early Miocene mammals from the eastern Mediterranean. Palaeobiodivers Palaeoenviron. 95:271-284.

Holman JA. 2000. Fossil snakes of North America: origin, evolution, distribution, paleoecology. Bloomington: Indiana University Press. 357 pp.

Hossini S. 1993. A new species of Latonia (Anura, Discoglossidae) from the lower Miocene of France. Amphibia-Reptilia. 14:237-245.

Ikeda T. 2007. A comparative morphological study of vertebrae of snakes occurring in Japan and adjacent regions. Curr Herpetol. 26:13-34.

Ivanov M. 1999. The first European pit viper from the Miocene of Ukraine. Acta Palaeontol Pol. 44:327-334.

Ivanov M. 2001. Changes in the composition of the European snake fauna during the early Miocene and at the early/middle Miocene transition. Paläontol Z. 74:563-573.

Ivanov M, Ruta M, Klembara J, Böhme M. 2017. A new species of Varanus (Anguimorpha: Varanidae) from the early Miocene of the Czech Republic, and its relationships and palaeoecology. J Syst Palaeontol 1-31.

Jackson K. 2002. How tubular venom conducting fangs are formed. J Morphol. 252:291-297.

Joyce WG. 2016. A review of the fossil record of turtles of the clade panchelydridae. Bull Peab Mus Nat Hist. 57:21-56.

Joyce WG, Parham JF, Gauthier JA. 2004. Developing a protocol for the conversion of rank-based taxon names to phylogenetically defined clade names, as exemplified by turtles. J Paleontol. 78:989-1013.

Klembara J. 1981. Beiträgzurkenntnis der subfamilie Anguinae (Reptilia, Anguidae). Acta Univ Carol - Geol. 2:121-168.

Klembara J. 2008. A new anguimorph lizard from the lower miocene of north-west bohemia, czech republic. Palaeontology. 51:81-94.

Klembara J. 2012. A new species of Pseudopus (Squamata, Anguidae) from the early Miocene of Northwest Bohemia (Czech Republic). J Vertebr Paleontol. 32:854-866.

Klembara J. 2015. New finds of anguines (Squamata, Anguidae) from the Early Miocene of Northwest Bohemia (Czech Republic). Paläontol Z. 89:171-195.

Klembara J, Hain M, Dobiašová K. 2014. Comparative Anatomy of the Lower Jaw and Dentition of Pseudopus apodus and the Interrelationships of Species of Subfamily Anguinae (Anguimorpha, Anguidae). Anat Rec. 297:516-544.

Koufos GD. 2006. The Neogene mammal localities of Greece: faunas, chronology, and biostratigraphy. Ann Geol des Pays Helleniques. 4:183-214.

Koufos G. 2013. Neogene mammal biostratigraphy and chronology of Greece. In: Wang X, Flynn LJ, Fortelius M, editors. Fossils mammals of Asia: neogene biostratigraphy and chronology. New York (NY): Columbia University Press; p. 595-626.
Koufos GD, Zouros N, Mourouzidou O. 2003. Prodeinotherium bavaricum (Proboscidea, Mammalia) from Lesvos island, Greece; the appearance of deinotheres in the eastern Mediterranean. Geobios. 36:305-315.

Koufos GD, Kostopoulos D, Vlachou T. 2005. Neogene/Quaternary mammalian migrations in Eastern Mediterranean. Belg J Zool. 135:181-190.

Kuch U, Müller J, Mödden C, Mebs D. 2006. Snake fangs from the Lower Miocene of Germany: evolutionary stability of perfect weapons. Naturwissenschaften. 93:84-87.

LaDuke TC. 1991. The fossil snakes of Pit 91, Rancho la Brea, California. Contrib Sci Nat Hist Mus Los Angeles County. 424:1-28.

Lartet E. 1851. Notice sur la colline de Sansan, suivie d'une récapitulation des diverses espèces d'animaux vertébrés fossiles, trouvés soit à Sansan, soit dans d'autres gisements du terrain tertiaire miocène dans le BassinsPyrénéen. Auch: J.-A. Portes; 42 pp.

Laurenti JN. 1768. Austriaci Viennensis specimen medicum, exhibens synopsin reptilium emendatam cum experimentis ca Venena et antidota reptilium Austriacorum quod authoritate et consensu. Vienna (Austria): Joannis Thomae de Trattnern, Caes. Reg. Maj. Aulae Typographi et Bibliopolae.

Linnaeus C. 1758. Systema naturae per regna tria naturae, secundum classes, ordines, genera, species cum characteribus, differentiis, synonymis, locis Tomus 1, Pars 1. Stockholm (Sweden): Laurentii Salvius.

Mendelssohn H, Steinitz H. 1943. A new frog from palestine. Copeia. 1943:231-233.

von Meyer H. 1843. Mittheilungen an Professor Bronn gerichtet. Neues Jahrb Mineral Geognosie. 1843:579-590.

Nopcsa F. 1923. Die Familien der Reptilien [The families of the Reptiles]. Fortschritte Geol Paläontologie. 2:1-210.

Oppel M. 1811. Die Ordnungen, Familien und Gattungen der Reptilien als Prodom einer Naturgeschichte derselben. München (Germany): Joseph Lindauer Verlag.

Owen R. 1857. On the fossil vertebrae of a Serpent (Laophis crotaloides, Ow.) discovered by Capt. Spratt, R.N., in a tertiary formation at Salonica. Q J Geol Soc London. 13:196-199.

Pyron RA, Burbrink FT, Wiens JJ. 2013. A phylogeny and revised classification of Squamata, including 4161 species of lizards and snakes. BMC Evol Biol. 13:93.

Rage J-C. 1984. Serpentes In: Wellnhofer P, editor. Encyclopedia of paleoherpetology. Stuttgart: Gustav Fisher Verlag; 80 pp.

Rage J-C. 2003. Oldest Bufonidae (Amphibia, Anura) from the Old World: a bufonid from the Paleocene of France. J Vertebr Paleontol. 23:462463.

Rage J-C. 2006. The lower vertebrates from the Eocene and Oligocene of the Phosphorites du Quercy (France): an overview. Strata. 13:161-173.

Rage JC. 2012. Amphibians and squamates in the Eocene of Europe: what do they tell us? Palaeobiodivers Palaeoenviron. 92:445-457.

Rage J-C. 2013. Mesozoic and Cenozoic squamates of Europe. Palaeobiodivers Palaeoenviron. 93:517-534.

Rage J-C, Hossini S. 2000. Les Amphibiens du Miocène moyen de Sansan. Mém Mus Natl d'Hist Nat. 183:177-217.

Rage J-C, Roček Z. 2003. Evolution of anuran assemblages in the Tertiary and Quaternary of Europe, in the context of palaeoclimate and palaeogeography. Amphibia-Reptilia. 24:133-167.

Rage J-C, Szyndlar Z. 2005. Latest Oligocene-Early Miocene in Europe: Dark Period for booid snakes. C R Palevol. 4:428-435.

Richter A. 1995. The vertebrate locality Maramena (Macedonia, Greece) at the Turolian-Ruscinian Boundary (Neogene). 3. Lacertilia (Squamata, Reptilia). Münchner Geowiss Abh. 28:35-38.

Roček Z. 1984. Lizards (Reptilia, Sauria) from the lower Miocene locality Dolnice (Bohemia, Czechoslovakia). Rozpravy Ceskoslovenské Akademie Ved, Rada Matematickych a prírodních Ved. 94:3-69.

Roček Z. 1994. Taxonomy and distribution of tertiary discoglossids (Anura) of the genus Latonia v. Meyer, 1843. Geobios. 27:717-751.

Roček Z. 2013. Mesozoic and Tertiary Anura of Laurasia. Palaeobiodivers Palaeoenviron. 93:397-439.

Rögl F. 1999. Mediterranean and Paratethys. Facts and hypotheses of an Oligocene to Miocene paleogeography (short overview). Geol Carpathica. 50:330-349. 
Römer F. 1870. Über Python Euboïcus, eine fossile Riesenschlange aus tertiärem Kalkschiefer von Kumi auf der Insel Euboea [On Python Euboïcus, a fossil giant snake from the tertiary shale of Kumi in the island of Euboea]. Z Dtsch geol Gesell. 22:582-590.

Schleich HH. 1994. Fossil Schildkröten- und Krokodilreste aus dem Tertiär Thrakiens (W-Türkei). Cour Forsch-Inst Senckenberg. 173:137-151.

Sen S, Antoine PO, Varol B, Ayyildiz T, Sözeri K. 2011. Giant rhinoceros Paraceratherium and other vertebrates from Oligocene and middle Miocene deposits of the Kağızman-Tuzluca Basin, Eastern Turkey. Naturwissenschaften. 98:407-423.

Sindaco R, Jeremčenko V. 2008. The Reptiles of the Western Palearctic Vol 1 Annotated Checklist and Distributional Atlas of the Turtles, Crocodiles, Amphisbaenians and Lizards of Europe, North Africa, Middle East and Central Asia. Belvedere: Monografie della Societas Herpetologica Italica I. Szyndlar Z. 1984. Fossil snakes from Poland. Acta Zool Cracov. 28:1-156.

Szyndlar Z. 1991a. A review of Neogene and Quaternary snakes of Central and Eastern Europe. Part I: Scolecophidia, Boidae. Colubrinae Estud Geol. 47:103-126.

Szyndlar Z. 1991b. A review of Neogene and Quaternary snakes of Central and Eastern Europe. Part II: Natricinae, Elapidae. Viperidae Estud Geol. 47:237-266.

Szyndlar Z. 2005. Snake fauna from the Late Miocene of Rudabánya. In: Bernor RL, Kordos L, Rook L, editors. Multidisciplinary research at Rudabánya Palaeontogr Ital. 90, p. 31-52.
Szyndlar Z. 2012. Early Oligocene to Pliocene Colubridae of Europe: a review. Bull Soc Géol France. 183:661-681.

Szyndlar Z, Rage J-C. 2003. Non-erycine Booidea from the Oligocene and Miocene of Europe. Kraków: Institute of Systematics and Evolution of Animals, Polish Academy of Sciences; 111 pp.

Theocharopoulos CD. 2000. Late Oligocene-Middle Miocene Democricetodon, Spanocricetodon and Karydomys n. gen. from the Eastern Mediterranean area. Gaia. 8:1-113.

Vasileiadou K, Zouros N. 2012. Early Miocene micromammals from the Lesvos Petrified Forest (Greece): preliminary results. Palaeobiodivers Palaeoenviron. 92:249-264.

Vasileiadou K, Böhme M, Neubauer TA, Georgalis GL, Syrides GE, Papadopoulou L, Zouros N. 2017. Early Miocene gastropod and ectothermic vertebrate remains from the Lesvos Petrified Forest (Greece). Pal Z 91(4):541-564.

Vasilyan D, Schneider S, Bayraktutan MS, Şen Ş. 2014. Early Pleistocene freshwater communities and rodents from the Pasinler Basin (Erzurum Province, north-eastern Turkey). Turkish J Earth Sci. 23:293-307.

Villa A, Delfino M, Luján ÀH, Almécija S, Alba DM. 2017. First record of Latonia gigantea (Anura, Alytidae) from the Iberian Peninsula. Hist Biol 1-12.

Zahradnicek O, Horacek I, Tucker AS. 2008. Viperous fangs: development and evolution of the venom canal. Mech Dev. 125:786-796. 